\title{
Mapping the Knowledge Domain of Smart-City Research: A Bibliometric and Scientometric Analysis
}

\author{
Li Zhao ${ }^{1}$, Zhi-ying Tang ${ }^{1}$ and Xin Zou ${ }^{2, *}$ \\ 1 College of Management Science, Chengdu University of Technology, Chengdu 610059, China; \\ lizhao@stu.cdut.edu.cn (L.Z.); tangzhiying@cdut.cn (Z.-y.T.) \\ 2 Institute of Transport Studies, Monash University, Clayton, VIC 3800, Australia \\ * Correspondence: Xin.Zou@monash.edu
}

Received: 13 October 2019; Accepted: 20 November 2019; Published: 25 November 2019

\begin{abstract}
As urbanization continues to accelerate, the number of cities and their growing populations have created problems, such as the congestion and noise related to transportation, the pollution from industry, and the difficulty of disposing of garbage. An emerging urban strategy is to make use of digital technologies and big data to help improve the quality of life of urban residents. In the past decade, more and more researchers have studied smart cities, and the number of literature in this field grows rapidly, making it "big data". With the aim of better understanding the contexts of smart-city research, including the distribution of topics, knowledge bases, and the research frontiers in the field, this paper is based on the Science Citation Index Expanded (SCIE) and Social Sciences Citation Index (SSCI) in the Web of Science (WoS) Core Collection, and the method used is that of comprehensive scientometric analysis and knowledge mapping in terms of diversity, time slicing, and dynamics, using VOSviewer and CiteSpace to study the literature in the field. The main research topics can be divided into three areas- "the concepts and elements of the smart city", "the smart city and the Internet of Things", and "the smart city of the future" - through document co-citation analysis. There are four key directions- "research objectives and development-strategy research", "technical-support research", "data-processing and applied research", and "management and applied research" - analyzed using keywords co-occurrence. Finally, the research frontiers are urban-development, sustainable cities, cloud computing, artificial intelligence, integration, undertaken through keyword co-occurrence analysis.
\end{abstract}

Keywords: Smart city; Scientometrics; Visualization; VOSviewer; CiteSpace

\section{Introduction}

With the growth of cities, urban development is facing enormous challenges, such as inefficient urban management, congested transportation, emergency protocols that are difficult to implement, and imperfect environmental-monitoring systems [1]. In order to improve urban management, the concept of the smart city, with IoT technology as its core, was born. The "smart city", through participatory governance, investment in human capital, and both traditional and modern communications infrastructure, can promote sustainable economic growth, improve the quality of life of residents, and allow sustainable and integrated management of natural resources [2]. In recent years, researchers in a variety of fields have been devoting more and more time to researching them. For example, Caragliu et al. [3] have conducted in-depth research into the dimensions of the smart city, and Zanella et al. [4] have researched its technology. This research area has produced many papers, and the construction of smart cities has become a priority of numerous countries. In China, the National Development and Reform Commission [5] released a "Notice on Organizing New Smart-City Evaluations and Promoting the Healthy and Rapid Development of New Smart 
Cities", while the United States government released a "Federal Cloud Computing Strategy" [6], which supports the application and development of big data as a national strategy.

In recent years some researchers have conducted overviews of the literature related to smart cities. A method of data taxonomy was proposed for major smart-city date entities [7]. Giffinger et al. [8] proposed that enhancements to urban life could be regarded in six dimensions: People, government, economy, mobility, environment, and living. Angelidou [9] classified smart cities as "new versus existing" cities, and divided smart-city projects into "soft" and "hard" implementations, as well as the factors affecting the influence of journals on smart-city development $[10,11]$. Ingwersen and Serrano-López [12] conducted a scientometric analysis of the literature from 1990-2016, dividing it into three time periods, but they confused the concept with similar ones, including smart, digital, intelligent, knowledge, sustainable, and green city(ies). Albino [13], meanwhile, had already clarified the differences among these. Mora et al. [14] combined multiple databases to study the literature related to smart cities from 1992-2012; however, we found only 19 documents in the WoS Core-Collection database for this period. Komninos and Mora [15] analyzed the literature on smart cities in terms of three structural axes based on the data provided by Mora et al. [14]. Li [16] studied co-keywords and bibliographic coupling in just two dimensions-STE (science, technology, and engineering) and SSH (social sciences and humanities), but it is also very interesting to study the development process of smart-city as presented in the classic documents. Moreover, the strength of the bibliographic coupling was fixed, while the co-citation strength was dynamic, making the co-citation analysis of the internal relationships of the scientific literature and the dynamic structure of scientific development better than the bibliographic coupling.

In summary, the bibliometric and scientometric analyses of the relevant smart-city studies still need further improvement. We do not know the distribution of research on smart-cities in the WoS Core-Collection database, whose authority is self-evident. These researchers have examined the smart-city literature from specific viewpoints (such as data, governance, or concept). However, about the knowledge bases of the research and its focuses-is it more interested in technology? e-governance? people? environment?-we know too little, and little research has been done on document co-citation and keyword co-occurrence. In order to fill these gaps, this paper tries to capture an overall picture of smart-city research, and detect its frontiers and knowledge bases. Our innovation is to summarize the knowledge bases using document co-citation, and to explore research hotspots through keyword co-occurrence. The goal of this paper is to provide a detailed overview of smart cities, based on the following research questions.

- What are the main source journals and discipline distribution in smart-city research?

- What are the distributions of research power in terms of countries, organizations, and authorship?

- What are the core research topics and their knowledge bases?

- What are the research hotspots and trends?

To answer these questions, this paper is based on SCIE and SSCI in the WoS Core Collection database, and the methods of scientometric analysis and knowledge mapping from the perspectives of diversity, time slicing, and dynamics, using VOSviewer and CiteSpace to comprehensively study the literature in the field. To analyze the areas of concentration in smart-city research by analyzing the distributions of research power (by country, organization, and author), to analyze the main research areas of different periods, and to seek the knowledge bases and further development of smart-city by document co-citation, keyword co-occurrence, and reference burst-detection is the object of this paper.

The remainder of the work is structured as follows: Section 2 introduces the bibliometric and scientometric methods to be used in this paper; Section 3 covers the yearly quantitative distribution of the publications, the main source journals, and distribution across disciplines, the main countries (territories), organizations, and countributors, and their degrees of cooperation, with document co-citation, reference burst-detection, and keyword co-occurrence in the field showing the results retrieved for this paper; and Section 4 is the conclusion, and deals with prospects for the future. 


\section{Methodology}

\subsection{Data Source and Processing}

This paper uses the documents indexed by SCIE and SSCI in the WoS Core Collection database owned by Clarivate Analytics as its source of literature. The retrieval topic "smart-city", "smart-cities" and document types "article" and "review" over a time span of "all years" (as of 4 October 2019) led to a total of 2920 papers. Using WoS as the search source guaranteed the quality of the literature and gave a solid basis to the analysis [17]. The database not only allows a comprehensive and standardized way of searching for information, but also covers the major journals of a variety of disciplines, including earth and atmospheric sciences, computer science, social sciences and humanities, and so on [18]. Compared with Scopus, the WoS data is better suited to VOSviewer and CiteSpace, and the "journal citation reports (JCR)" tool and "create citation report" function in WoS were used in this paper.

\subsection{Analytical Methods and Tools}

As documents have become more numerous, the weakness of traditional bibliometrics has become more obvious in terms of its subjectivity, incompleteness, and time-consuming nature. Comprehensively understanding and the evaluation of the literature in a given field requires a more scientific bibliometric. Scientometrics involves quantitative assessment of scientific activities based on bibliometrics and statistics, and provides decision-makers with easy-to-understand quantitative data [19]. The evaluation indicators are quite objective [20]. Peer researchers form an objective "citation-network" relationship through mutual citations in papers and other works, and scientometrics is based on these. It has universal authority and credibility [21], and makes use of the internationally renowned literature-search tool. The Scientific Citation Index (SCI), whose selections are based on Garfield's Law of Document Sets and Bradford's Discrete Law, has strict standards and procedures, and is also both economical and fast [20].

A knowledge map is a kind of graph showing the relationship between the development process and the structure of scientific knowledge. It takes scientific knowledge as the research object, applies mathematics, information science, computer science, and other subject areas, and develops laws on the basis of a variety of methods and techniques to produce the two-dimensional figure known as a knowledge map [22]. With improvements in computer processing, electronic information, and the patent authorization of documents, knowledge maps have become more and more powerful as methods of data visualization, enabling researchers to analyze and assess the trends and research frontiers of subject areas. Many tools exist for producing scientific-knowledge maps, and each software tool has characteristics, techniques, and algorithms specific to it [23]. BibExcle allows preprocessing of textual data to be performed and bibliometric networks to be extracted [24], but it does not allow for adequate visualization of the output. CoPalRed has a great de-duplication feature, but is focused only keywords [25]. Network Workbench (NWB) and Sci2 have de-duplication modules and good network-reduction features, but require external software [23]. VOSviewer has a good manual for constructing and visualizing bibliometric maps of any kind of co-occurrence data [26]. CiteSpace has a large wiki in which major problems are dealt with, and its main object is to promote analysis of trends in a knowledge field [27]. Both CiteSpace and VOSviewer were developed using the Java programming language, and therefore can be applied to any platform. This is why we have decided to use them here. These two software tools have seen the fastest and most widespread adoption of any tools used in library and information-science research [28].

VOSviewer, developed by van Eck and Waltman [26], has many common bibliometric functions, including bibliographic coupling, co-authorship, co-occurrence, and co-citation analysis. The software has been widely used in scientometric analysis in many domains: Library and information science [29], medicine [30,31], computer science [32], biology [33], and education [34]. CiteSpace, developed by Chen [27], as a tool for producing knowledge maps, can identify and display new trends and developments in a subject area through analysis of the literature, and can detect the research progress, 
current research frontiers, and knowledge bases of such an area. Researchers can "capture" a field at different moments in time, then connect the captured images in order to understand the essential characteristics of the research frontiers and their evolution, define the research field, and identify new research trends.

\section{Results}

\subsection{Yearly Quantitative Distribution of Literature}

In Figure 1, the historical development of smart-city research can be seen to have three stages: Exploration, initial development, and rapid development.

- Exploratory stage (1999-2009): Only five publications were found at this stage. The earliest one was published in City with the title: "Smart Cities—The Singapore Case" [35]. This paper describes the measures taken by the government of Singapore to adapt to the inevitable movement from an industrial to an information economy. In the late 1990s, the term of the "smart city" was proposed as a way of coping with urban population growth and solving problems of economic and social development, construction of urban infrastructure, quality of life, and environmental ecology in the process of urbanization [36]. Singapore's "Smart Island" project was a typical example of smart-city construction during this period, emphasizing the integration and management of important pieces of urban infrastructure, urban public-resource optimization, security monitoring, and risk management by way of modern information technology [35].

- Initial development stage (2010-2013): 94 publications were found for this stage, with average annual growth of 15. Since 2010, the European Smart City Organization, IBM Corporation, the Natural Resources Protection Committee, and other research institutions have gradually deepened their understanding of the significance of the process of exploring the nature of smart cities, and gradually an internationally recognized definition has taken shape: That a smart city involves the use of computer technology to enable the deep integration of IT, social, and commercial infrastructures [1]. It has been pointed out that information and communication technologies (ICTs) are the driving force of the smart-city development [37]. The combination of consciousness fusion and smart technology is the key to supporting the construction of smart urban [3]. During this stage, the study of smart cities from the perspective of information technology attracted the attention of academic communities. Based on ICTs, scholars studied the technical support level of smart cities, focusing on how to use cloud computing, social networking and business intelligence, fourth-generation mobile-communications technology (4G), and other technological innovations to support urban construction and management.

- Rapid development stage (2014-2018): In this stage, the results of research have been rapidly emerging, and more than 100 papers are being published every year. The average annual growth is 175. Especially since 2016, the number of documents has risen sharply. With advances in computer technology, research on smart cities based on computer science continues to receive attention. Simultaneously, in terms of management, urban planning [13], the environment, and other aspects, research into the smart cities has continued to emerge, gradually forming a fusion across disciplines and industries to establish a smart-city research network [38]. The focus of this research has begun to shift from network-technology innovations and applications [4] to the economies, societies, cultures, ecological environments, and use of energy resources in smart cities [13] — that is, from a focus on hardware that values urban infrastructure to one on software that focuses on human and social capital [39]. In this way, the studies of smart cities have continued to evolve. 


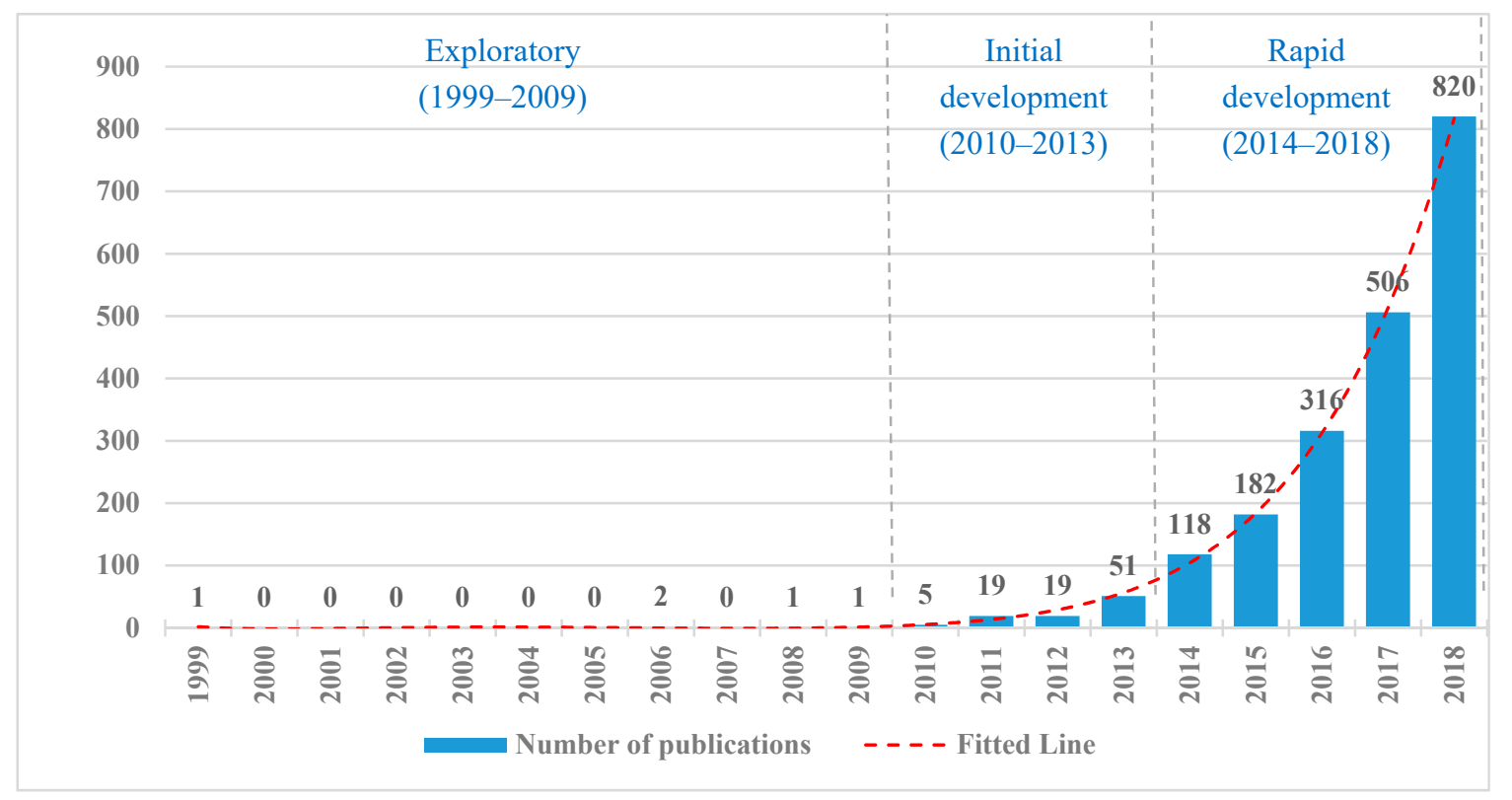

Figure 1. Annual distribution of publications of smart-city research. (Note: As the data in 2019 is still updating, it is not included in this figure.)

\subsection{Main Source Journals and Discipline Distribution}

Academic journals are important carriers of the achievements in a given academic discipline. Through analysis of source journals, the distribution of core journals in a field can be found. According to the search results, there are 558 journals in categories covering "Engineering, Electrical \& Electronic", "Telecommunications", and "Computer Science, Information Systems". Top 10 journals with numerous papers about smart cities are listed in Table 1. The top three journals in terms of the number of publications in this field are, IEEE Access, Sensors, and Sustainability, with documents numbering 219, 219 , and 110, respectively. A TC/TP (citations per publication) of 9.63 and impact factor of 3.557 put IEEE Access at the top of the three. Analysis of the top 10 journals showed that the TC/TP value was one of the factors affecting impact factor. In general, the higher the number of average citations of publications by a journal is, the higher its impact factor is. Among the JCR categories, the main research areas are "Computer Science, Information Systems", "Engineering, Electrical \& Electronic", and "Sustainability" among the top 10 journals for smart-city papers.

Figure 2 shows the distribution of disciplines in this field over the last 10 years; the hotter the color is, moving from left to right, the more documents related to smart cities appeared in a certain subject area in a certain year. The most relevant categories of documents related to smart cities are "Engineering Electrical \& Electronic", "Telecommunications", and "Computer Science, Information Systems". The numbers of documents for these were 696,693 and 647, respectively, and they have increased rapidly since 2014. From this we can see that the discipline distribution inclines toward "technical engineering" when it comes to smart-city research. This is because the process of actually building a smart city needs to be supported by lots of technologies that help realize the interconnection of fields; strengthening the technical research into smart cities is particularly important. 
Table 1. Top 10 source journals in smart-city research.

\begin{tabular}{|c|c|c|c|c|c|c|c|}
\hline Rank & Journal & TP & TC & TC/TP & $h$-Index & IF & JCR Category \\
\hline 1 & IEEE Access & 219 & 2108 & 9.63 & 25 & 3.557 & $\begin{array}{ll}\text { - } & \text { Computer Science, } \\
\text { Information Systems } \\
\text { - } \quad \text { Engineering, Electrical \& Electronic } \\
\text { - } \quad \text { Telecommunications }\end{array}$ \\
\hline 2 & Sensors & 219 & 1561 & 7.13 & 19 & 2.475 & $\begin{array}{ll}\text { - } & \text { Chemistry, Analytical } \\
\text { - } & \text { Electrochemistry } \\
\text { - } & \text { Instruments \& Instrumentation }\end{array}$ \\
\hline 3 & Sustainability & 110 & 522 & 4.75 & 12 & 2.075 & $\begin{array}{ll}\text { - } & \text { Environmental Sciences } \\
\text { - } & \text { Environmental Studies } \\
\text { - } & \text { Green\& Sustainable } \\
& \text { Science \& Technology }\end{array}$ \\
\hline 4 & Future Generation Computer Systems & 84 & 1660 & 19.75 & 19 & 4.639 & $\begin{array}{l}\text { - Computer Science, } \\
\text { Theory \& Methods }\end{array}$ \\
\hline 5 & Sustainable Cities and Society & 76 & 672 & 8.84 & 13 & 3.073 & $\begin{array}{ll}\text { - } & \text { Construction \& } \\
& \text { Building Technology } \\
\text { - } & \text { Energy \& Fuels } \\
\text { - } & \text { Green\& Sustainable Science } \\
& \text { \& Technology }\end{array}$ \\
\hline 6 & IEEE Communications Magazine & 72 & 2514 & 34.92 & 27 & 9.27 & $\begin{array}{ll}\text { - } & \text { Engineering, Electrical \& Electronic } \\
\text { - } & \text { Telecommunications }\end{array}$ \\
\hline 7 & IEEE Internet of Things Journal & 70 & 2803 & 40.04 & 19 & 5.874 & $\begin{array}{ll}\text { - } & \text { Computer Science, } \\
& \text { Information Systems } \\
\text { - } & \text { Engineering, Electrical \& Electronic } \\
\text { - } & \text { Telecommunications }\end{array}$ \\
\hline 8 & Cities & 57 & 1616 & 28.35 & 18 & 2.704 & - Urban Studies \\
\hline 9 & Technological Forecasting and Social Change & 48 & 636 & 13.25 & 9 & 1.787 & $\begin{array}{ll}\text { - } & \text { Business } \\
\text { - } & \text { Panning Development }\end{array}$ \\
\hline 10 & Journal of Urban Technology & 40 & 1713 & 42.83 & 14 & 3.213 & - Urban Studies \\
\hline
\end{tabular}

Note: TP = Total Publications; TC = Total Citations; TC/TP = Citations per Publication; IF = 2017 Impact Factor; Data Sources: WoS.

No Categories

1 Engineering, Electrical \& Electronic

2 Telecommunications

3 Computer Science, Information Systems

4 Instruments \& Instrumentation

5 Green \& Sustainable Science \& Technology

7 Electrochemistry

8 Chemistry, Analytical

6 Computer Science, Theory \& Methods

9 Environmental Studies

10 Computer Science, Software Engineering
Year

$2010201120122013201420152016201720182019 \quad$ Total

\begin{tabular}{|c|c|c|c|c|c|c|c|c|c|c|c|}
\hline 0 & 1 & 2 & 17 & 31 & 30 & 83 & 14 & 26 & 128 & $\square$ & 69 \\
\hline 0 & 2 & 2 & 23 & 35 & 31 & 87 & 15 & 24 & 115 & $\square$ & 693 \\
\hline 3 & 5 & 3 & 11 & 24 & 33 & 87 & 14. & 21 & 122 & $\square$ & 64 \\
\hline 0 & 0 & 3 & 6 & 6 & 33 & 29 & 45 & 76 & 56 & $\square$ & \\
\hline 0 & 0 & 1 & 2 & 3 & 12 & 17 & 41 & 97 & 38 & 口 & \\
\hline 0 & 0 & 3 & 5 & 4 & 29 & 26 & 31 & 66 & 39 & 口 & \\
\hline 0 & 0 & 3 & 5 & 4 & 29 & 27 & 28 & 6 & 40 & $\square$ & \\
\hline 3 & 5 & 1 & 2 & 4 & 7 & 14 & 46 & 68 & 45 & 7 & \\
\hline 0 & 1 & 0 & 6 & 11 & 11 & 23 & 43 & 5 & 33 & 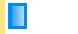 & \\
\hline 3 & & 1 & 8 & 15 & 12 & 23 & 34 & 42 & 28 & & \\
\hline
\end{tabular}

Figure 2. Main discipline distribution of smart-city research in recent ten years. 


\subsection{Main Countries (or Territories) and Their Cooperation}

The retrieved publications were from 93 countries, with the top 4 being China (608), the USA (506), Spain (388), and Italy (351), with proportions of $20.82 \%, 17.32 \%, 13.28 \%$, and $12.02 \%$ respectively. As shown in Table 2, among the top five countries, although China ranks first in number of publications, its TC/TP value is low, at 9.04. This shows that although China has produced a large variety of publications in the field, their overall quality needs to improve. From its $h$-index ( $h$ papers have each been cited at least $h$ times) of 35 , it ranks second, meaning that of the 608 papers published by authors from China, 35 have been cited at least 35 times. In Table 2 we can also see that Italy's TC/TP value and TC (total citations) value rank first, indicating that the quality of the Italian literature is generally high in this field.

Table 2. 10 most productive countries (or territories) in smart city research.

\begin{tabular}{ccccccc}
\hline Rank & Country & Region & TP & TC & TC/TP & $\boldsymbol{h}$-Index \\
\hline 1 & China & East Asia & 608 & 5498 & 9.04 & 35 \\
2 & USA & North America & 506 & 6805 & 13.45 & 41 \\
3 & Spain & Southwestern Europe & 388 & 4091 & 10.54 & 29 \\
4 & Italy & Southern Europe & 351 & 8467 & 24.12 & 33 \\
5 & England & Northwestern Europe & 290 & 5003 & 17.25 & 34 \\
6 & Australia & Australia & 169 & 2191 & 12.96 & 23 \\
7 & Republic of Korea & East Asia & 164 & 1878 & 11.45 & 22 \\
8 & Canada & North America & 155 & 2863 & 18.47 & 26 \\
9 & India & South Asia & 154 & 951 & 6.18 & 17 \\
10 & France & Western Europe & 105 & 1023 & 9.74 & 17 \\
\hline
\end{tabular}

Note: Abbreviations are available in Table 1.

Here we will introduce the smart-city development in the four countries. In China, at the national level, in the period of the "13th Five-Year Plan", China's smart-city policies were published intensively, and include "Guidance on Promoting the Healthy Development of Smart Cities" [40] and "Notice on Organizing New Smart-city Evaluation to Promote Healthy and Rapid Development" [5]; these have mainly promoted e-government, smart transportation, big data, and the Internet of Things, as well as improvements in the smart-city evaluation-index system. Since 2012, China has established smart-city pilot projects in many cities. As of May 2019, 100\% of sub-provincial and higher cities, including more than $76 \%$ of prefecture-level cities and $32 \%$ of county-level cities, or a total of about 500 cities, have proposed building new smart cities [41]. Since 2013, China's smart-city construction has entered a peak period, with the pace constantly accelerating, and making a great contribution to its social and economic development. At the regional and enterprise level, the launch of 5G networks and the support of the three major operators (Telecom, Mobile Unicom) of wireless communications and broadband equipment will greatly accelerate the smart-city development.

In the U.S., the Federal Cloud Computing Strategy [6] was released in 2018, and gives priority to using cloud computing to solve problems with e-government efficiency and big-data strategic planning, and to support the country's big-data applications and development in relation to national strategies. The city of Dubuque, with a population of roughly 60,000 in 2009, established the first smart city in the U.S., using Internet of Things technology to connect various urban public resources and put in place real-time monitoring, analysis, and dynamic response [42]. From a regional and corporate perspective, New York City is the leader in the smart-city development in the U.S. The city has developed a digital strategic plan based on urban resources and needs, and has developed a city-data road map on the basis of research into the interests of urban residents [9]. In addition, New York has promoted the Hudson Yards Project, and installed a large number of electronic detectors in the commercial and residential areas of western Manhattan, using digital technology to produce traffic, energy, and air-quality data in real time [43]. 
In Spain, from 19-21 November 2019, the 9th Smart City Expo World Congress (SCEWC) was held in Barcelona, Spain (www.smartcityexpo.com) to focus on technological innovations, as well as solutions in the fields of new energy sources, the Internet of Things, sustainable development, smart power, mobile transportation, and so on. Additionally, SmartSantander (www.smartsantander.eu) has made a commitment to creating an unparalleled European experimental test facility for research into architectures, enabling technologies, services, and applications of the IoT. Infrastructure for this project will be mainly deployed by Santander in the north of Spain [44]. The program is funded by the European Union (EU) and has attracted the attention of leading companies from Europe and across the world [45].

To create a basis for building smart cities, Italy, since 2002, has focused on the use of information technology in relation to broadband, digital signatures, distance education, e-libraries, telemedicine, and so on. The establishment of a "public-centered government" is its basic goal, with the government establishing "remote classrooms" for hospitalized children and installing smart meters throughout the country to build intelligent power-information systems [46]. Milan is the leader in this area, emphasizing energy conservation, and the protection of cultural heritage and the environment, in the process of building smart cities [47]. In terms of transportation, Milan's green transportation construction has paid special attention to public transport and bicycle sharing, along with $\mathrm{Wi}-\mathrm{Fi}$, information centers, and other services.

In VOSviewer, co-authorship analysis within countries was used to gain an overview of the areas of concentration and cooperation within these countries in relation to smart-city research. Figure 3 gives such an overview of the main countries. In it, the more papers have been published in a given country, the larger its node is. China, the USA, Spain, and Italy are at the center, radiating toward their surroundings. The connections among nodes represent the closeness of connection between two countries: The thicker the line, the closer the relationship. In Figure 3, the centers are closely connected while their surroundings are scattered; the lines connecting the USA and China are the thickest, and the colors of their nodes are similar, indicating that the two countries are closely connected, followed by Spain and Italy. The countries with closer links rank higher, which shows that the progress and development of the new field requires exchanges among different countries or territories, and that the experiences of these places promote the development of other places.

\subsection{Main Organizations and Their Cooperation}

The search results show that there are 2408 organizations related to smart-city research, the top ten of which are shown in Table 3. In this table, there is not a large range in the total number of publications pertaining to each organization, with the first having 46 , and the bottom 22 . The 10 organizations are universities at which a total of 290 papers have been produced, accounting for $9.66 \%$ of the total. Among the 2408 organizations, 2319 , or $96.3 \%$ of all organizations, have produced fewer than 10 papers. This indicates that the production of papers is concentrated in a few organizations. It also shows that the distribution of organizations is wide and scattered in the field of smart-city research. Half the organizations in the top 10 in Table 3 are Chinese universities, indicating that Chinese scholars are particularly interested in the smart-city development. The high quality (TC/TP) of the documents from Italy is also notable; in Table 3, the three organizations from Italy, namely, the University of Bologna (UNIBO), the Polytechnic University of Milan (PolyMi), and the Polytechnic University of Turin (PolyTu), have high TC values of 896, 831, and 919, respectively. It can be seen from the TC/TP value that the top three are PolyTu, PolyMi, and the UNIBO, with values of 41.77, 33.24, and 27.15, respectively. The remaining seven organizations have TC/TP values below 20 . 


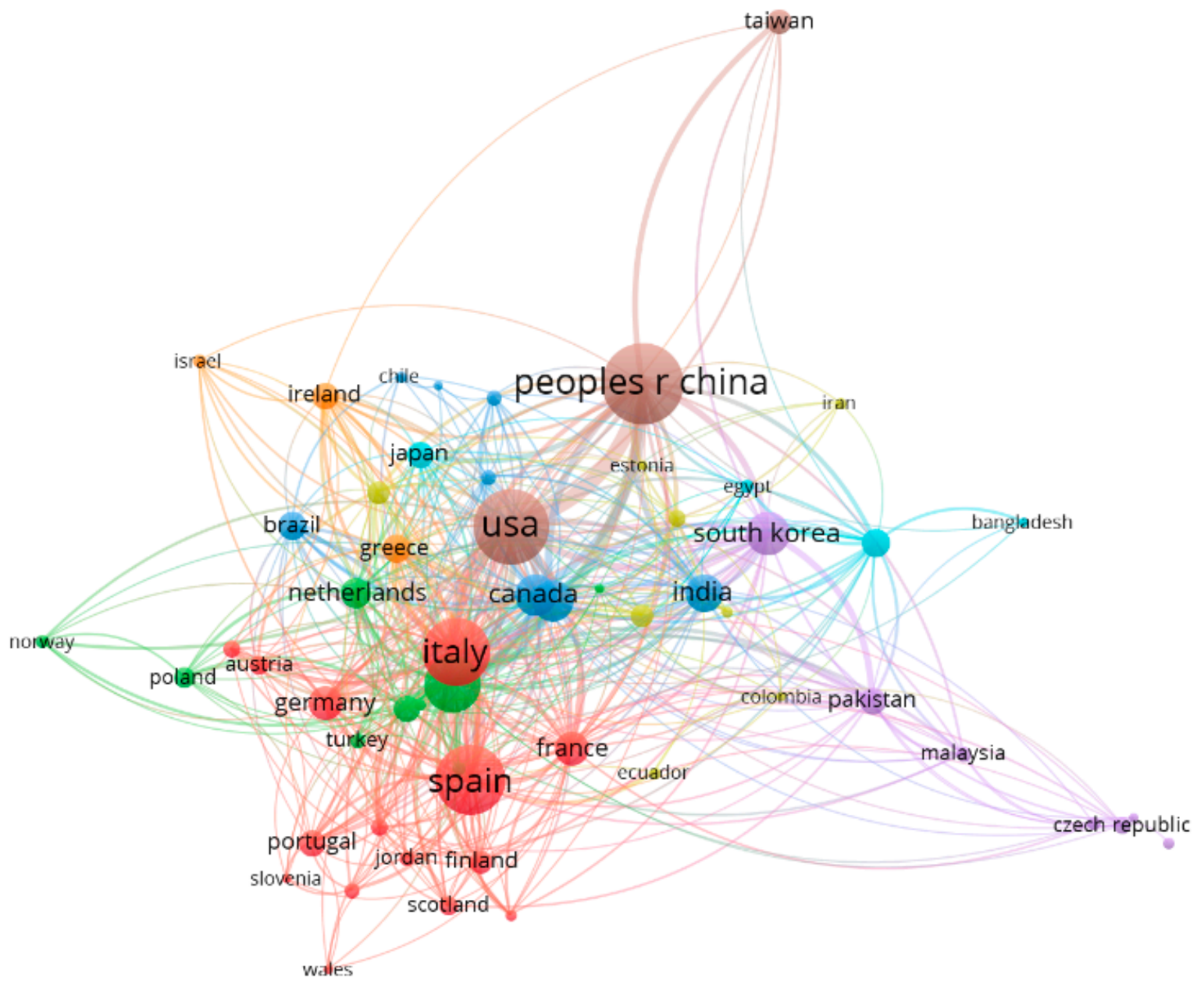

Figure 3. Collaboration among main countries or territories.

Table 3. Top 10 productive organizations in smart-city research.

\begin{tabular}{cccccccc}
\hline Rank & Organization & Country & TP & Percentage & TC & TC/TP & $\boldsymbol{h}$-Index \\
\hline 1 & Chinese Academy of Science & China & 46 & $1.635 \%$ & 430 & 10.24 & 11 \\
2 & Univ. of Bologna & Italy & 36 & $1.285 \%$ & 896 & 27.15 & 11 \\
3 & King Saud Univ. & Saudi Arabia & 31 & $1.129 \%$ & 377 & 13 & 11 \\
4 & Wuhan Univ. & China & 28 & $1.012 \%$ & 132 & 5.08 & 6 \\
5 & Shanghai Jiao Tong Univ. & China & 27 & $1.012 \%$ & 102 & 3.92 & 5 \\
6 & Dalian Univ. of Technology & China & 27 & $0.973 \%$ & 429 & 17.16 & 12 \\
7 & Polytechnic Univ. of Milan & Italy & 27 & $0.973 \%$ & 831 & 33.24 & 10 \\
8 & Delft Univ. of Technology & Netherlands & 23 & $0.895 \%$ & 322 & 14 & 8 \\
9 & Huazhong Univ. of Science \& Technology & China & 23 & $0.895 \%$ & 333 & 14.84 & 9 \\
10 & Polytechnic Univ. of Turin & Italy & 22 & $0.865 \%$ & 919 & 41.77 & 8 \\
\hline
\end{tabular}

Note: Abbreviations are available in Table 1.

In VOSviewer, the strength of cooperation among organizations can be analyzed through their co-authorship. In Figure 4, each node represents an organization, and its size represents the number of documents it has produced related to smart cities. The color of the node represents the group to which the organization belongs based on the default clustering method. The connections in the network map represent the cooperation among organizations; the wider the line, the stronger the cooperation. In Figure 4, there are 196 nodes, 15 clusters, and 578 links. It can be seen that the organizations on the left are close together, indicating strong connections, while those on the right are farther apart, and need to strengthen their cooperation. 


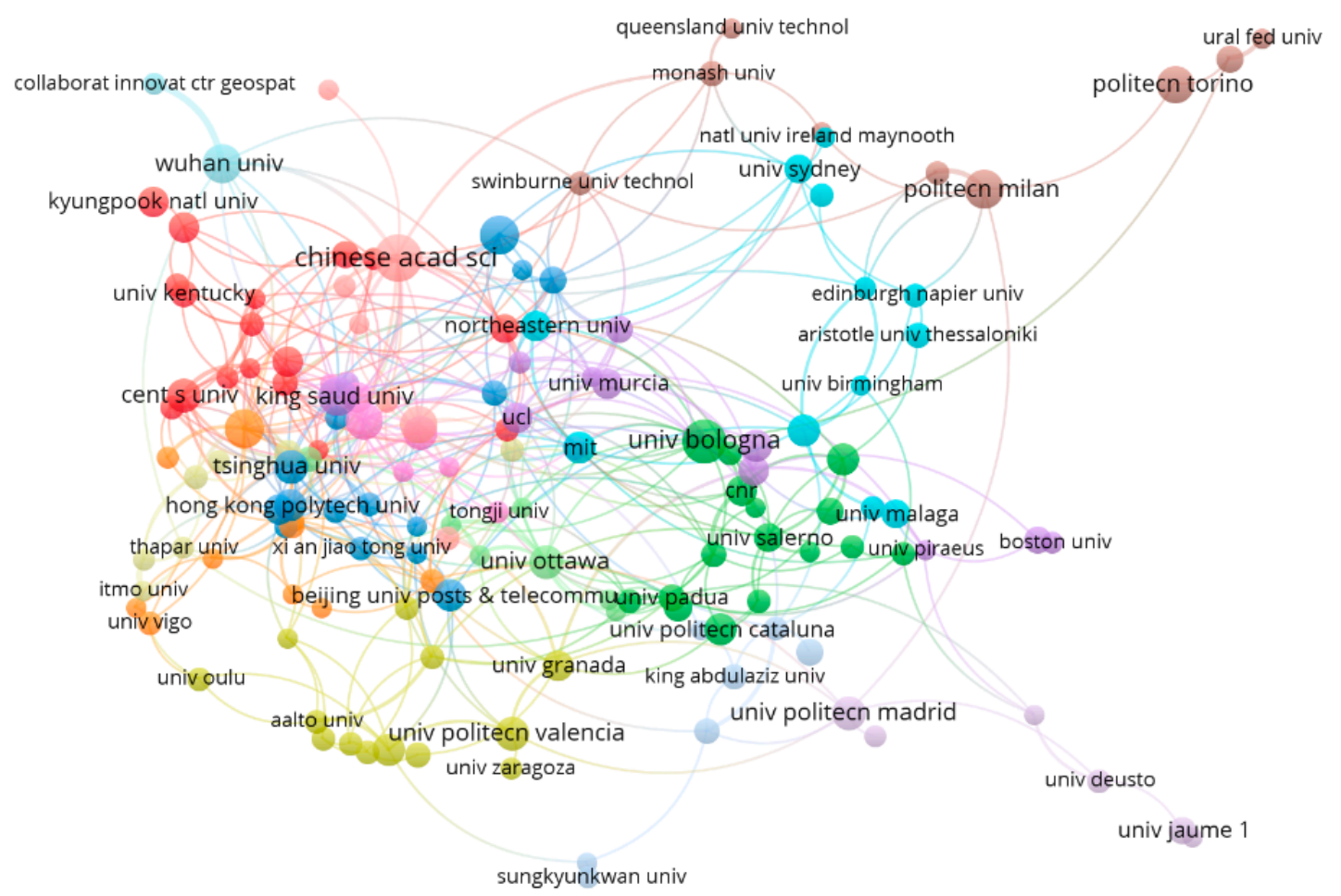

Figure 4. Collaboration network among main research organizations.

\subsection{Main Contributors and Their Cooperation}

Smart-cities is a field of research that encompasses multiple disciplines, and includes researchers from fields such as mathematics, computer science, political science, economics, and environmental science. In VOSviewer, we can identify author collaboration on the topic of smart cities, as shown in Figure 5. Analysis of such collaboration allows us to assess its levels and visualize the current status of research. Communication among experts from different fields promoted the development of this field.

Since volume of publications is also an important indicator, Table 4 offers rankings on this basis, and co-citations will be researched in the following sections. In Figure 5, each node represents an author, the size of the node represents the number of his or her documents, and the color of the node represents the group to which the contributor belongs based on the default clustering method. The lines in the network represent contributor partnerships. The wider a line, the stronger the cooperation. There are 99 nodes, 38 clusters in Figure 5. Table 4 and Figure 5 show that the top ten contributors are mainly from the countries with the highest number of publications: China, the USA, Spain, and Italy. However, only one contributor belongs to one of the top 10 organizations. Also, the top ten authors belong to groups that are near each other and tightly connected, while the distribution of the other groups is relatively loose. Based on the number of a contributor's publications, group 1 (yellow) is represented by Prof. Luis Muñoz, group 2 (red) by Assistant Prof. Houbing Song, and group 3 (cyan-blue) by Associate Prof. Neeraj Kumar. In terms of contributor citations, group 4 (gray), represented by Assistant Prof. Luca Foschini, who has the highest number at 339, followed by group 2 (red), still represented by Assistant Prof. Houbing Song, and group 1 (yellow), still represented by Prof. Luis Muñoz. In general, the more cooperation among contributors, the more they promote the development of the field. As can be seen from Figure 5, contributor cooperation needs to be strengthened in this field, and contributors are the main factors in its development. It is necessary to strengthen the communication among them in order to promote the development of the field. 


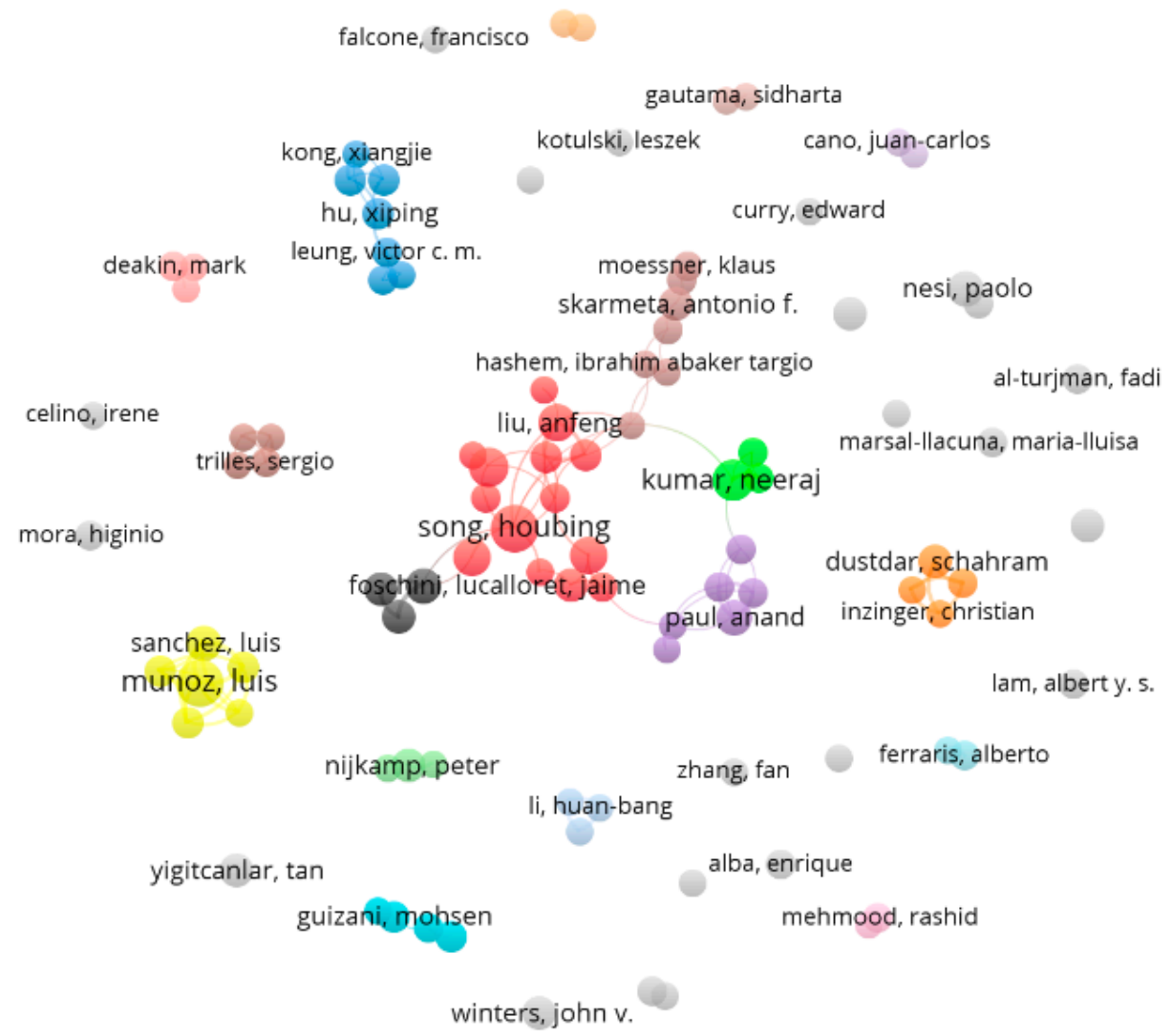

Figure 5. Co-authorship network among productive authors.

Table 4. Top 10 productive contributors in smart-city research.

\begin{tabular}{cccccccc}
\hline Rank & Author & Organization & Country & TP & TC & TC/TP & $\boldsymbol{h}$-Index \\
\hline 1 & Luis Muñoz & Univ. of Cantabria & Spain & 16 & 306 & 19.13 & 7 \\
2 & Houbing Song & Embry-Riddle Aeronautical Univ. & USA & 15 & 344 & 22.93 & 9 \\
3 & Neeraj Kumar & Thapar Institute of Engineering \& Technology & India & 17 & 109 & 7.79 & 6 \\
4 & Kim-Kwang Raymond Choo & Univ. of Texas at San Antonio & USA & 16 & 102 & 7.85 & 6 \\
5 & Anfeng Liu & Central South Univ. & China & 12 & 167 & 13.92 & 8 \\
6 & Burak Kantarci & Clarkson Univ. & USA & 14 & 155 & 14.09 & 7 \\
7 & Arun Kumar Sangaiah & Vellor Institute of Technology & India & 10 & 42 & 4.2 & 4 \\
8 & Luis Sánchez & Univ. of Cantabria & Spain & 10 & 279 & 27.7 & 6 \\
9 & Paolo Nesi & Univ. of Florence & Italy & 10 & 68 & 6.8 & 5 \\
10 & Luca Foschini & Univ. of Bologna & Italy & 9 & 339 & 37.67 & 6 \\
\hline
\end{tabular}

Note: Abbreviations available in Table 1.

\subsection{Document Co-citation Analysis}

In 1973, American information scientist Henry Small published a paper titled "Co-Citation in the Scientific Literature: A New Measure of the Relationship between Publications" [48]. He was the first to propose the concept of co-citation analysis. Document co-citation occurs when two documents appear together in the references of a third, and mining of the co-citation relationships of documents through a spatial data set can be considered document co-citation analysis. This analysis efficiently and conveniently locates the core literature (knowledge bases) in a research field from among the mass of cited references, and can analyze and mine the correlations and development contexts of the documents. The academic influence of the references can be quantified to some extent by the two indices of co-citation frequency and intermediate centrality. As shown in Figure 6, through document co-citation analysis, smart-city research can be divided into three main clusters; red, green, and blue. There are 78 nodes, 2230 links, and 10,735 co-citations. The red cluster has the highest research nodes, with 37 , followed by the green cluster at 27 , and the blue with 14 . Table 5 shows the classic documents with high numbers of co-citations in smart-city research. 


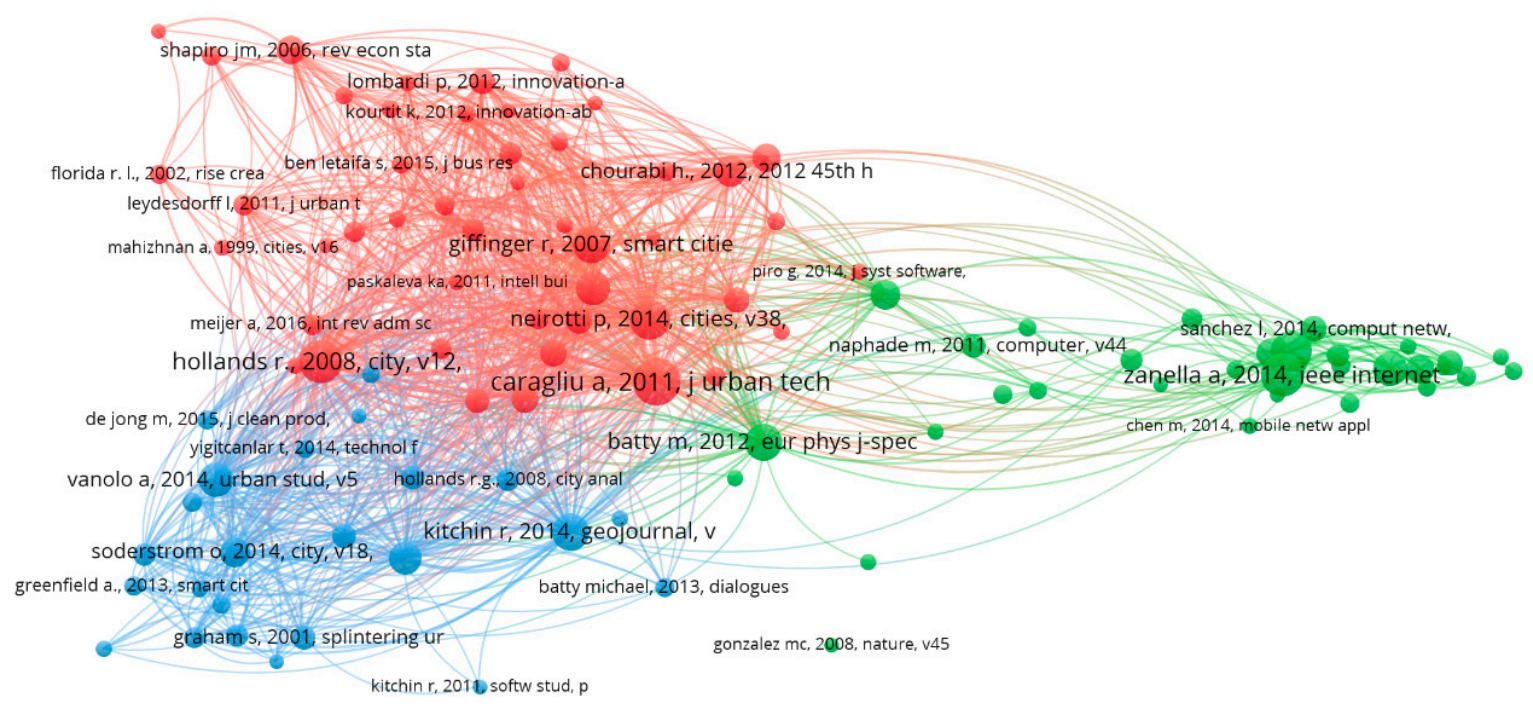

Figure 6. Document co-citation network of smart city studies.

Table 5. Classic documents with high co-citations in smart-city research.

\begin{tabular}{|c|c|c|c|c|}
\hline Cluster (Color) & Title & Author/s & Published in & Co-Citations \\
\hline \multirow{3}{*}{1 (red) } & "Smart cities in Europe" & Caragliu et al. [3] & $\begin{array}{c}\text { Journal of } \\
\text { Urban Technology }\end{array}$ & 1049 \\
\hline & $\begin{array}{l}\text { "Current trends in smart city initiatives: } \\
\text { some stylised facts" }\end{array}$ & Neirotti et al. [49] & Cities & 841 \\
\hline & $\begin{array}{l}\text { "Will the real smart city please stand up? Intelligent, } \\
\text { progressive or entrepreneurial?" }\end{array}$ & Hollands [50] & City & 795 \\
\hline \multirow{3}{*}{2 (green) } & "Internet of things for smart cities" & Zanella et al. [4] & $\begin{array}{l}\text { IEEE Internet of } \\
\text { Things Journal }\end{array}$ & 438 \\
\hline & "The internet of things: a survey" & Atzori et al. [51] & Computer Networks & 405 \\
\hline & $\begin{array}{l}\text { "Internet of Things (IoT): a vision, architectural } \\
\text { elements, and future directions" }\end{array}$ & Gubbi et al. [52] & $\begin{array}{l}\text { Future Generation } \\
\text { Computer Systems }\end{array}$ & 306 \\
\hline \multirow{3}{*}{3 (blue) } & "The real-time city? Big data and smart urbanism" & Kitchin [53] & GeoJournal & 638 \\
\hline & $\begin{array}{l}\text { "Smartmentality: the smart city as } \\
\text { disciplinary strategy" }\end{array}$ & Vanolo [38] & Urban Studies & 607 \\
\hline & "Critical interventions into the corporate smart city" & Hollands [54] & $\begin{array}{l}\text { Journal of Regions, } \\
\text { Economy and Society }\end{array}$ & 302 \\
\hline
\end{tabular}

\subsubsection{Cluster 1 (red): The Concepts and Elements of The Smart City}

In this cluster, the researchers mainly devise and perfect the concepts and elements of smart cities from different perspectives. For example, they start from different subjects (government, enterprises, or individuals); some put a top-down emphasis on technology $[4,55]$, some a bottom-up emphasis on the needs of citizens [2,3,39,56-59], and some give dialectical explanations of smart-city terminology $[39,50,60]$.

The classical document with the greatest co-citations is called "Smart Cities in Europe", by Caragliu et al. [3], published in the Journal of Urban Technology. Its number of co-citations is 1,049. In this paper, Caragliu et al. [3] conducted a comprehensive study of the concept of smart cities through a case study of European smart cities, and concluded that in their development, while hard infrastructure is important, social (soft) infrastructure is equally so, and plays a decisive role in urban competitiveness. This has made up for the limitations of previous research that focused only on hard infrastructure (ICT). Based on this, Nam and Pardo [59] further analyzed the conditions of a smart-city development considering technology, people, and institutions. Neirotti et al. [49] explored the smart-city development in relation to economic, urban, demographic, and geographic variables [13,61]; And Castelnovo et al. [62] stated that citizens should be the center of the process of assessment; Boes et al. [63] think that cities will become "smarter" by increasing their investment in soft 
power and human capital in the process of building "smart" tourism; follow-up research has continued to study the roles of human and social capital, ICTs, and participatory governance in improving quality of life [2,39,56-58].

Published in Cities by Neirott et al. [49], a paper titled "Current Trends in Smart City Initiatives: Some Stylised Facts" has 841 co-citations. The authors present an exhaustive comprehension of the concept of the smart city through an elaboration of a taxonomy of the areas. Through examples, they show that the evolution of smart cities depends on local context. For example, economic development and structural urban variables may affect the digital development of smart cities; geographic location will affect their strategies; and population density will affect their implementation. Based on this, Yu et al. [64] analyzed the gigantic data in the building field by data mining to frame the energy-effective communities. Many researchers have studied sustainable smart cities. For example, Ahvenniemi et al. [65] distinguished "sustainable" and "smart" through urban-assessment frameworks, and proposed a "smart sustainable city"; the researchers further studied its framework, trends, and challenges [66,67]; and Bibri [68] advocated the Internet of Things for promoting sustainable urban development.

A document entitled "Will the Real Smart City Please Stand Up? Intelligent, Progressive or Entrepreneurial?" by Hollands [50], published in City. It has had 795 co-citations. Its main innovation is to think critically about smart cities, such as considering the polarization of society. Hollands analyzed the five main characteristics of smart cities through examples of a large number of cities, as well as problems related to the uncoordinated development of these five characteristics in smart cities. These include the slivering impacts of the informational cities, the limitations of urban entrepreneurialism, the issues that innovative classes cause in local communities, urban inequality, and the contradiction between environmental sustainability and economic growth. Hollands stated that, in order to truly develop a smart city, one must accept great technical risk, develop power, address inequality, and redefine the meaning of "smart" itself. Based on this, Caragliu et al. [3] conducted the relationships among the five characteristics of smart cities. Chourabi et al. [60] laid out smart-city initiatives, including micro and macro levels. Nam and Pardo [59] asserted that the key to urban success is human interaction, and that IT alone cannot promote urban development. Like any other form of urban development, smart cities will face integration and restructuring problems [38], and at the global level, urban development has both positive and negative effects [69].

\subsubsection{Cluster 2 (green): The Smart City and The Internet of Things}

In this cluster, research is mainly focused on the technology of smart-cities, including IoT, cloud computing, fog computing, edge computing, and other cutting-edge areas.

The paper, "Internet of Things for Smart Cities" [4] was published in the IEEE Internet of Things Journal, and had 438 co-citations. The authors specifically looked at the "Urban Internet of Things", considering this as a sort of smart-city vision making use of the most advanced communication technologies to support the management services of cities and citizens. This research also looked in-depth at supporting technologies, protocols, and frameworks of the Urban IoT. Following up on this research, Schaffers et al. [44] looked at the use of IoT monitoring in smart cities for addressing transportation issues, and air quality assessments for improving citizens' lives. Roman et al. [70] proposed a centralized and distributed IoT architecture model to address the unique security challenges facing IoT. Whitmore et al. [71] focused on the impact of IoT on infrastructure and found that integrating these technologies can improve the flexibility, reliability, and efficiency of infrastructure operations to reduce manpower and costs. Additionally, Sethi and Sarangi [72] conducted a study on the impact of the IoT on people's lifestyles (especially for the elderly) and proposed a new taxonomy of IoT technology. Finally, Qiu et al. [73] examined the application of a heterogeneous IoT in modern life and the complex challenges that must be addressed [74].

Published in the Journal of Computer Networks [51], "The Internet of Things: A Survey" had 405 co-citations. The authors studied sensing and communication technologies, middleware 
and service management in the IoT, and identified key areas for further research including standardization activity, network issues, and security and privacy. Subsequent research has increased understanding of the hard domain of smart-cities in terms of environment, logistics, and healthcare [49]. In terms of the soft domain, research has focused on social security and welfare [49], education and culture, and emerging communications technology: IoT [75-77], cloud computing [78-80], and second-generation RFID technology [81]. Additionally, Gubbi et al. [52] proposed a cloud-centric vision for worldwide implementation of the IoT through the convergence of wireless-sensor networks (WSNs), the internet, and distributed computing directed at the technological-research community. Furthermore, Al-Fuqaha et al. [82] explored the relationship between IoT and emerging technologies including data analysis, cloud computing, and fog computing, as well as horizontal integration between IoT services. Finally, Giang et al. [83] proposed a distributed data-stream (DDF) programming model based on fog computing.

Another important piece of research is "Internet of Things (IoT): A Vision, Architectural Elements, and Future Directions" [52], published in Future Generation Computer Systems, with 306 co-citations. In this paper, the authors looked at technologies, applications, cloud platforms, architecture, energy consumption [84], security issues, service quality, and IoT data mining. They developed a user-centric, cloud-based model taking into account the individual needs of different users and proposed a scalable "cloud" framework to effectively separate various IoT elements. Building on this research, Mijumbi et al. [85] studied the complementary relationship between network function virtualization (NFV), software-defined networking (SDN), and cloud computing, arguing that NFV may reduce operational and capital expenditures. As for further research, Botta et al. [86] integrated the IoT and the "cloud" to develop the concept of CloudIoT, elaborating on complementary factors that drive integration and offering predictions for their future direction. Additionally, Shi et al. [87] proposed the use of edge computing for IoT and cloud computing. The authors highlighted the technology's potential to address response time requirements, battery life constraints, bandwidth costs, data security, and privacy. Finally, Walravens [88] provided practical suggestions for improving application economy and mobile services in the Brussels region using IoT technology.

\subsubsection{Cluster 3 (blue): The Smart City of The Future}

In this cluster, researchers have mainly focused on the pros and cons of different aspects of smart-city development. For example, Kitchin [53] examined the advantages and disadvantages of big data approaches for the smart-city development; Vanolo [38] observed a tendency in the high-tech sector to over-celebrate social and environmental opportunities, while relegating social importance to the invisible periphery; and Shelton et al. [89] advocated better knowing the risks and long-term consequences of smart-city models, rather than using ideal scenarios to sway enterprises, policymakers, and the public.

The study that has had the largest co-citations which is 638 thus far has been "The Real-time City? Big Data and Smart Urbanism" [53], published in GeoJournal. The author paid close attention to the impact of big data on smart-cities, highlighting ways that big data can provide real-time analysis for life, new governance models and raw materials (including data) for creating more efficient, sustainable, open, and transparent cities. Nevertheless, Kitchin also found that big data has potential negative consequences for the smart-city development. For example, the rapid rate of urbanization comes with serious concerns about maintaining stability, and privacy issues related to high transparency of information. Based on this, follow-up research has looked more closely at the application of big data. Kitchin [90] additionally explored the ways that big data analysis has attracted the attention and imagination of a growing range of practitioners and scholars, no longer confined to Information System. Big data phenomena have been characterized as "great floods", which may have long-term effects on practice and academia [91]. In recent years, increasingly sophisticated big data analysis capabilities have been widely used to enhance business performance, though only a handful of companies have displayed true positive effectiveness [92]. Big data also holds the potential to do things like alleviate 
traffic congestion and address urban inequality related to rapid population growth [93]. Worth noting, Sheng et al. [94] developed a comprehensive framework using data-driven approaches to link multiple research processes in organization, operations, marketing, information management, and other key areas. Nevertheless, smart cities still have a series of shortcomings in terms of their development [95]. When applying ICT models, it is essential to make adjustments for different regional and environmental contexts [96].

Published in the journal Urban Studies, another paper worthy of discussion is "Smartmentality: The Smart City as Disciplinary Strategy" [38], with 607 co-citations. The research mainly analyzed critical political issues associated with smart cities, shifting the focus from technology to people and discussing how smart cities can become a powerful disciplinary tool for cultivating intelligent citizens with technical knowledge [56,97]. Vanolo asserted that three things were of special importance for the development of smart cities: (1) Simplifying smart city development problems through the use of multiple statistical indicators. (2) Promoting new public-private partnerships. (3) Empowering local communities and citizens. Based on this, follow-up research has continued to examine technical and citizenship dialectical relations. Notably, Buhalis and Amaranggana [98] found that public-private partnerships are essential for the development of Smart Tourism Destinations programs. It has additionally been seen that the smart-city development was made possible through a combination of enterprise vision, urban governance of entrepreneurs and a more-educated citizenry [54]. Still, the development of smart-cities must take into better account the relationship between social development and economic growth, with all aspects integrated systematically through strategy, rather than focusing on one aspect $[99,100]$. Finally, researchers expressed a need to reduce the utopianism that emerged through reducing the technicalism and introducing the new moral requirements in urban management [56].

Published in the Journal of Regions, Economy and Society, "Critical Interventions into the Corporate Smart City" [54] had 302 co-citations. The author examined the ways that the building of a smart-city is rooted in the beginnings of city construction and its attendant social problems, with technology used to realize progressive ideas, rather than being seen as progressive in and of itself [101]. The paper also argued that urban issues were not technical issues, but rather social issues, and that smart cities had not placed adequate emphasis on issues of equality and civil rights. Because the concept and driving force for smart cities have lacked detailed pedigrees [53], their development has run the risk of being divorced from reality, which some researchers have been examining in greater detail. Kummitha and Crutzen [102] proposed a 3RC (Restrictive, Reflective, Rationalistic, and Critical schools) framework critical analysis to examine problems at various stages in the smart-city development. Additionally, Anthopoulos [103] highlighted the differences separating utopia from reality in smart-cities by analyzing 10 representative urban cases. Finally, researchers have found that attention must be paid to reflect the interests of citizens and avoid an over-emphasis on technology resulting in urban policies focused on technology and causing urban development to deviate from reality $[104,105]$.

\subsection{Reference Burst-detection Analysis}

Kleinberg [106] first proposed a burst-detection algorithm (BDA); which looks at the density of citation-frequency changes within a domain to identify citations with high concentration and large density characteristics. BDA often used to discover sudden increases in the rate of recurrence of usage of subject terminology in a research area. When burst detection is performed on a body of literature, the burst strength of that body, and the start and end years of the bursts, can be obtained as a basis for analyzing the research trends in a given field. Figure 7 and Table 6 show the top 10 literature in the field of smart cities as detected in this manner. 
References

HOLLANDS R, 2008, CITY, V12, P303

GIFFINGER R, 2007, SMART CITIES RANKING, V0, P0 SHAPIRO JM, 2006, REV ECON STAT, V88, P324, DOI NAPHADE M, 2011, COMPUTER, V44, P32, DOI

KOMNINOS N, 2008, REG CITIES, V37, P1

HOLLANDS RG, 2008, CITY ANAL URBAN TREN, V3, P303, DOI 2008 WASHBURN D, 2010, HELPING CIOS UNDERST, V0, P0 CARDONE G, 2013, IEEE COMMUN MAG, V51, P112, DOI TRANOS E, 2012, INNOVATION-ABINGDON, V25, P175, DOI MITTON N, 2012, EURASIP J WIREL COMM, V0, P0, DOI

\begin{tabular}{rrr}
\multicolumn{3}{c}{ Year Strength Begin End } \\
2008 & $\mathbf{2 4 . 6 9 3 4} 2014$ & 2016 \\
2007 & $\mathbf{1 4 . 8 5 8 7} 2012$ & 2015 \\
2006 & $\mathbf{8 . 7 1 3 2} 2011$ & 2014 \\
2011 & $\mathbf{7 . 9 2 4} 2014$ & 2017 \\
2008 & $\mathbf{6 . 6 4 8 6} 2011$ & 2016 \\
I 2008 & $\mathbf{5 . 1 2 5 6} 2013$ & 2015 \\
2010 & $\mathbf{5 . 0 0 9 1} 2014$ & 2017 \\
2013 & $\mathbf{4 . 7 2 5} 2014$ & 2016 \\
2012 & $\mathbf{4 . 3 3 0 3} 2014$ & 2016 \\
2012 & $\mathbf{4 . 3 3 0 3} 2014$ & 2016
\end{tabular}

$1992-2019$

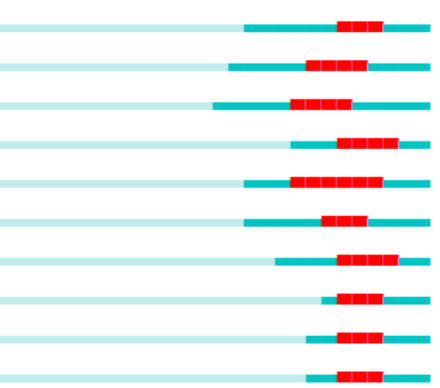

Figure 7. Top 10 references with the strongest citation bursts.

Table 6. Top 10 references with the strongest citation bursts.

\begin{tabular}{|c|c|c|c|c|c|}
\hline No & Title & Author/s (Year) & Published in & Strength & Burst Period \\
\hline 1 & $\begin{array}{l}\text { Will the real smart city please stand up? } \\
\text { Intelligent, progressive or entrepreneurial? }\end{array}$ & Hollands [50] & City & 24.6934 & 2014-2016 \\
\hline 3 & $\begin{array}{l}\text { Smart cities: quality of life, productivity, } \\
\text { and the growth effects of human capital }\end{array}$ & Shapiro [107] & Review of Economics and Statistics & 8.7132 & 2011-2014 \\
\hline 5 & $\begin{array}{l}\text { Intelligent cities and globalisation of } \\
\text { innovation networks }\end{array}$ & Komninos [109] & Regions and Cities & 6.6486 & 2011-2016 \\
\hline 6 & $\begin{array}{l}\text { Helping CIOs understand "smart city" } \\
\text { Initiatives: defining the smart city, its } \\
\text { drivers, and the role of the CIO. }\end{array}$ & Washburn et al. [1] & (Report) & 5.0091 & 2014-2017 \\
\hline 9 & $\begin{array}{l}\text { Combining cloud and sensors in a smart } \\
\text { city environment }\end{array}$ & Mitton et al. [112] & $\begin{array}{c}\text { Journal on Wireless } \\
\text { Communications and Networking }\end{array}$ & 4.3303 & 2014-2016 \\
\hline 10 & $\begin{array}{l}\text { Understanding individual human } \\
\text { mobility patterns }\end{array}$ & Gonzalez et al. [113] & Nature & 4.0985 & 2013-2015 \\
\hline
\end{tabular}

The largest such paper is that of Hollands [50], which was widely cited in 2014-2016, with a burst strength of 24.6934. Citations research shows that numerous scholars have researched the concept of the smart-city $[3,8,9,49,58,59,114,115]$, ICT and human-capital complementarity $[9,49,53,114,116]$, and the pros and cons of smart cities $[3,9,38,54,89,115]$. The concept of the smart city has been around for beyond 20 years, but the smart city does not yet have unified standards, and is therefore attracting more and more scholars to study it. A city ultimately exists to serve its residents, and therefore research into the smart city has gradually turned more and more toward humans and society, focusing less on technology. Everything has two sides, and the smart city is no exception. Obviously, a clear understanding of its advantages and disadvantages, and not blind development, will lead to the development of such cities.

The paper by Giffinger et al. [8] reports a burst strength of 14.9581, and was heavily quoted between 2012 and 2015. Their report distinguishes among six concepts (people, governance, economy, mobility, environment, and living) to define smart cities, and gives benchmarking indicators for 70 cities in Europe, providing a reference for many researchers. Similarly, the eighth paper by Tranos and Gertner [111] also studies the concept of a smart city, and mainly from a global inter-city perspective in Table 6. Study of their citations indicates that economics, people, governance, mobility, environment, and life [2,49,60,114,115,117-119], as well as the quantitative criteria that define smart cities [38,116,120], were the hot research directions. Demands for quality of life is constantly growing, and therefore people and the environment are increasingly indispensable parts in the smart-city development. 
The paper by Shapiro [107] has a literature burst strength of 8.7132 , and was heavily quoted from 2011 to 2014. Shapiro uses econometric methods to demonstrate the role of human capital in promoting urban development, with its direct effect being to increase urban productivity, and its indirect effect being to increase urban amenities. Gonzalez et al. [113] also started from studying the basic laws of human motion and trajectories to found the effects of this kind of movement of the human body on modeling such as urban planning. Study of their citations in the literature shows that a large number of researchers have used his conclusions to show the importance of human capital to urban development $[2,3,13,116,121]$.

The paper by Naphade et al. [108] has a burst strength of 7.924, and was heavily quoted between 2014 and 2017. The authors highlight how cities will collect data from a large range of urban sensors in the future, and follow-up researchers have further studied the technological advances involved in, and challenges brought about by, the combination of CoT and sensors [79,80,112,122-125].

The book by Komninos [109] has a burst strength of 6.6486, and was heavily quoted from 2011 to 2016. In it, the author explores what an intelligent city is, that is, how we should define it. What makes some cities and regions more effective in developing knowledge, technology, and innovation? How important is the external urban environment to the performance of an organization? How does innovation change with digitization and globalization? Follow-up researchers have studied related concepts such as intelligent, digital, and creative cities [69,99,126,127].

The paper by Washburn et al. [1] reported a burst strength of 5.091, and was heavily quoted from 2014 to 2017. These authors believe that intelligent computing will enable the various elements of a city to operate efficiently and intelligently. The literature citing this paper found that its followers understand the driving forces of smart cities [99,114,128], the opportunities and challenges surrounding smart mobile devices [76,129], and the uses and development of smart water networks $[130,131]$. The burst strength of the paper by Cardone et al. [110] is 4.752, and this research was widely quoted from 2014 to 2016. The authors investigated how and to what extent the power of collective intelligence, however imprecise, can be used in smart cities, proposing a crowd sensing platform featuring an innovative Android-based geo-social model and matching algorithm. Research on the literature in which it was cited found that follow-up researchers conducted further research on mobile crowd sensing [132-136]; and information-centric platforms $[137,138]$

\subsection{Keywords Co-occurrence Analysis}

Keyword co-occurrence analysis is universal in scientometric analysis. It mainly studies the link strengths among co-occurrence keywords in a large variety of literature. Its function is to analyze the internal relationship of an academic field and reveal the frontiers of research within it. These frontiers are the conceptual combinations of temporary research topics and basic research questions, as well as theoretical trends and new topics that are becoming more significant or are unexpected. In Figure 8 , we can see that through keyword co-occurrence analysis, the main research directions can be divided into four clusters, with the keywords within clusters of the same color having great similarities.

\subsubsection{Cluster 1 (red): Research Objectives and Development-Strategy Research Direction}

(The co-occurrence keywords include city, model, sustainability, information, innovation, governance, politics, technology)

Internationally, many scholars have studied the goals of smart-city construction, emphasizing that it should be green and people-oriented, realizing a vision of sustainable urban economic, social, and environmental development [58]. The construction goals can be categorized as urban industrial development, urban operational efficiency, urban technological innovation, and urban life and leisure. Based on these goals, the current development-strategy research focuses mainly on: (1) Tapping the driving forces of smart-city development and innovation, deepening the integration of digital technologies, and researching new ideas and models [55,72,83,139]; (2) developing top-level smart-city design and phased action plans to improve smart-city evaluation standards and norms [13,59-61]; 
(3) exploring the transformation of government functions and models of social management, focusing on e-democracy and multi-sectoral communications within policy formulation and urban governance, considering the relationships among governments, businesses, academia, and communities in relation to "intelligent vision", and building a government-led, multi-participate, and multidisciplinary collaborative mechanism for constructing smart cities $[3,50,51]$.

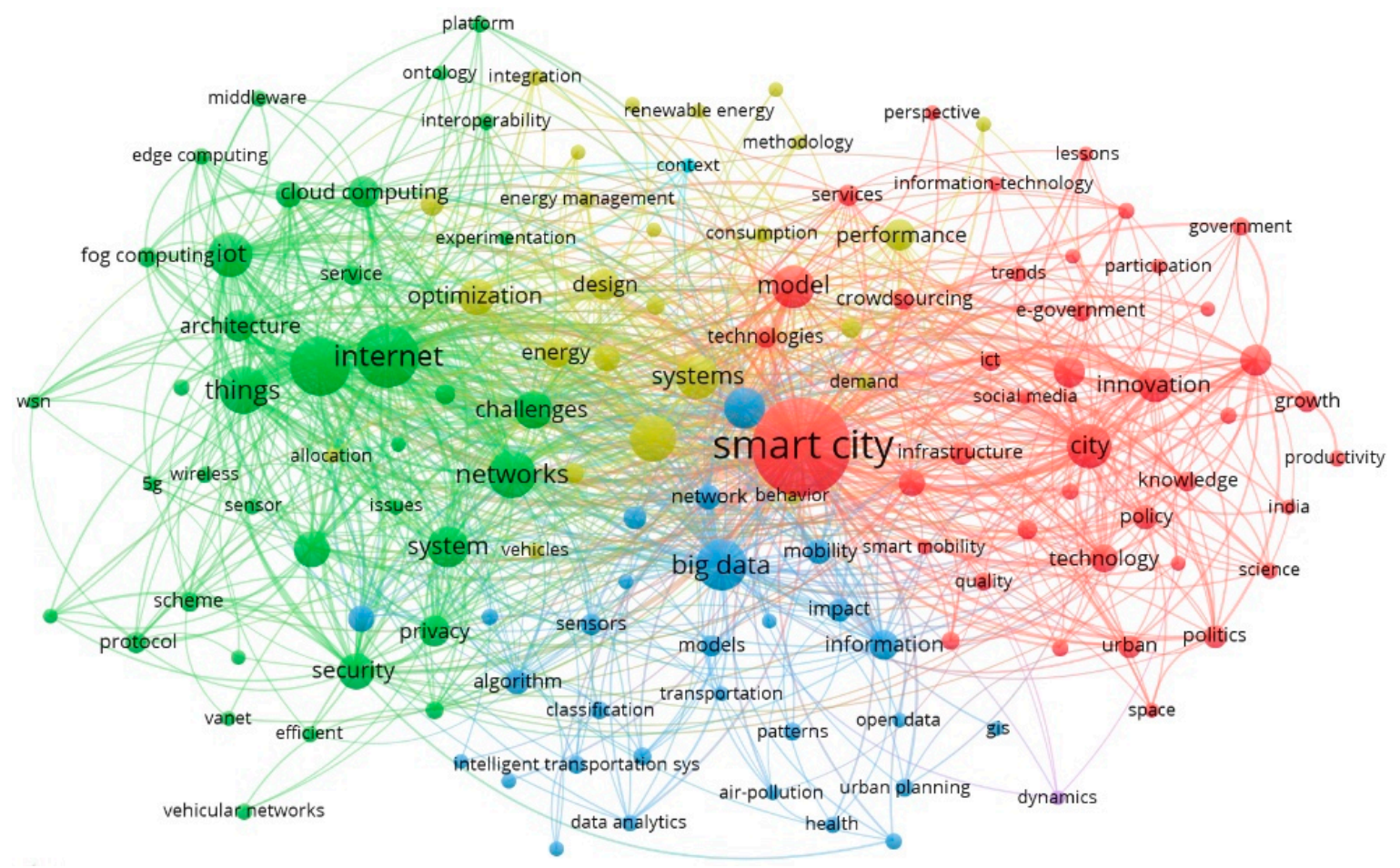

Figure 8. Keywords co-occurrence network of smart-city research.

\subsubsection{Cluster 2 (green): Technical-support Research Direction}

(The co-occurrence keywords include network, internet, Internet of things, system, wireless sensor network, security, privacy, cloud computing, architecture)

In the process of intelligent development and the automation of cities, advanced information systems play a leading role. Achieving comprehensive integration and perception of smart city management information will require extensive interconnection, efficient analysis, and intelligent processing powered by ICT, Internet applications, and mobile communications. The current focus of smart city research is in areas including IoT, sensor networks, and cloud computing. Through technology integration, a four-level network - consisting of perception, network support structure, data integration and analysis, and management and application layers-can serve as the framework for realizing urban "human-social-natural" integration and making urban services (e.g., smart parking, maintenance) and monitoring (e.g., transportation networks, tourist attractions, environmental pollution, and weather conditions) more comprehensive, efficient, and interactive.

\subsubsection{Cluster 3(blue): Data-processing and Applied Research Direction}

(The co-occurrence keywords include big data, pattern, prediction, information, data analytics, classification)

So far in the 21st century, the development of ICT and digital economies has made "big data" a focus for developing capabilities in analyzing dynamic changes, strategic decision-making, and forecasting in urban management [140]. Its main benefit is its applicability to massive, high-growth and diversified modern urban information development needs over previous information processing and analysis models. Currently, research on smart cities is mainly focused on social network data [53], specifically 
data mining storage [141], data classification analysis [75], and data security privacy [93]. Applications for more intelligent applications in areas including the energy environment [142,143], logistics and transportation [144-146], and medical education to better meet individual needs are also examined.

\subsubsection{Cluster 4 (yellow): Management and Applied Research Direction}

(The co-occurrence keywords include management, system, performance, design, optimization, smart grid, energy)

At present, significant global research has been conducted looking at the intelligent development of transportation, medical care [147], environment, education, life, public safety, and public management. While Gouveia and Fonseca [148] explored environmental monitoring using a smart city ICT approach, Jin et al. [149] looked at the use of smart city IoT platforms for monitoring urban information and communications. Additionally, Toppeta [150] examined the infrastructure of smart cities, focusing on aspects related to physics, information technology, society, and business. Eremia et al. [151] studied the connection between smart-city and smart-grid [152]. Future smart-city management is still rooted in big data approaches, with sensor network technology as the core. The focus is on developing data infrastructure, urban environment, urban public safety, construction, and other fields of data perception, monitoring, and sharing platforms, while also promoting development and improvement of smart services in various industries.

\subsubsection{Frontier Analysis of Keywords Co-occurrence}

Figure 9 shows trends in the co-occurrence of keywords in smart cities in recent years. For exploring research on the cutting edge, examining these trends holds great promise. The color gradient (blue to yellow) in Figure 9 represents trends in keyword co-occurrence from 2016 to 2018, which include, "fog computing, efficient, blockchain [153], supply chain, artificial intelligence, edge computing, deep learning, operation, electric vehicle, 5G, urban-development, sustainable city, mutual authentication and integration". As for the keywords related to the topic of "research objectives and development-strategy research direction", they include, "urban-development, lessons, sustainable city and supply chain". This illustrates the ways that current and future smart-city construction goals and development strategies are continuing to promote sustainable development based on lessons learned from previous urban development. Related to "technical-support research direction", keywords were "5G, fog computing, edge computing and efficient". "Technical support" refers to the development of fog computing and edge computing based on the IoT and cloud computing in combination with 5G technology to provide efficient technical support for the smart-city development. Related to "data-processing and applied research direction", keywords were "deep learning and artificial intelligent". At present, machine learning in a big data environment has become a topic of common focus among academia and industry, and for the related topic of "management and applied research direction", keywords were "integration, operation and electric vehicle". Multidisciplinary research that integrates all aspects of smart-cities is critical. Additionally, for the special function in the construction of green cities, electric vehicles have also attracted extensive attention from the academic community. 


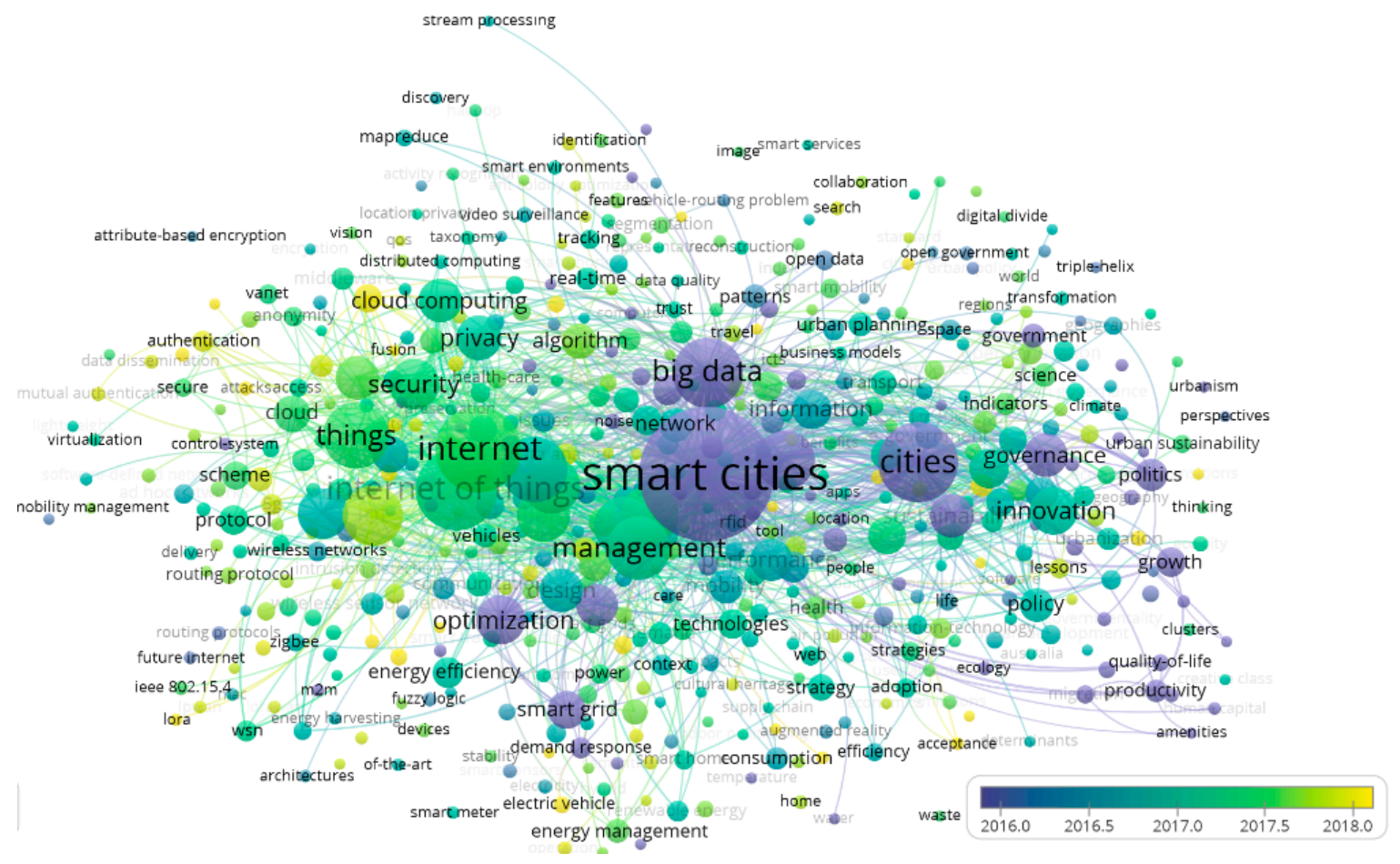

Figure 9. Overlay visualization in keywords co-occurrence network of smart city.

\section{Conclusions}

In order to better understand the development, knowledge bases, and contexts of smart cities, as well as the topic distribution in the field, based on scientometric software including VOSviewer and CiteSpace, this paper systematically sorts the relevant international research results, producing a visual analysis of 2920 articles in SSCI and SCIE of the WoS core collection database. The main conclusions are:

- The evolution of smart city research can be divided into three stages: exploration (1999-2009), initial development (2010-2013), and rapid development (2014-2018). As for source journals and discipline distribution in this filed, IEEE Access, Sensors, and Sustainability have been the top three journals in terms of number of publications, with discipline distribution leaning toward "technical engineering". This includes "Engineering Electrical \& Electronic", "Telecommunications", and "Computer Science, Information Systems". In terms of article distribution, the top four countries were China, the USA, Spain, and Italy, with their combined research providing abundant insights into the smart-city development. Although Italy ranks fourth in terms of distribution, the quality of the research has been very high. As the global body is still very scattered in nature, it is critical that cooperation among countries is strengthened. The largest number of documents was attributed to the Chinese Academy of Sciences, while the most-cited work came from Italy's PolyTu. There are huge potential future research possibilities given better cooperation among these key research organizations. As for co-authorship, individual researchers with the most published documents were Prof. Luis Muñoz (University of Cantabria) for Spain, Assistant Prof. Houbing Song (Embry-Riddle Aeronautical University) for the U.S., and Assistant Prof. Neeraj Kuma (Thapar Institute of Engineering \& Technology) for India. While regional cooperation is relatively strong, there is a need to strengthen international cooperation efforts.

- Through document co-citation analysis, the main research topics of smart-city research have been identified and divided into the categories of "the concepts and elements of the smart city", "the smart city and the Internet of Things", and "the smart city of the future". This paper analyzes the most widely cited classical literature in three areas: "the concepts and elements of 
the smart city" $[3,49,50]$; "the smart city and the Internet of Things" [4,51,52]; "the smart city of the future" $[38,53,54]$. For examining development trends for literature in this field, CiteSpace software was used to analyze the literature in the field of smart cities using burst-detection. In looking at the 10 highest-burst pieces of literature, it was found that between 2011 and 2017, researchers paid more attention to human resources and environmental sustainability while conducting vertical excavation of technology.

- Analysis of keyword co-occurrence has also served to reveal areas of highest activity for smart city research, and they are "research objectives and development-strategy research direction" including sustainable, smart design, innovation, policy, energy, and future research; "technical-support research direction", emphasizing core topics including IoT, cloud computing, and wireless sensor networks; "data-processing and applied research direction" focuses on data analysis, prediction, data risk control, and research across a range of fields. Finally, "management and applied research direction", with a focus on infrastructure, sensor networks, environment, security, architecture, optimization, and services; As for keyword co-occurrence on the frontiers of smart city analysis, these include "urban-development, lessons, sustainable city, supply chain, 5G, fog computing, edge computing, efficient, deep learning, artificial intelligence, integration, operation, and electric vehicle composition". For the category "research objectives and development-strategy research direction", keywords were, "urban-development, lessons, sustainable city and supply chain". For the category "technical-support research direction", keywords were "5G, fog computing, edge computing, and efficient", while for the category of "data-processing and applied research direction", keywords were "deep learning and artificial intelligence". Finally, for the category "management and applied research direction", keywords were "integration, operation and electric vehicle".

- Through in-depth analysis of keyword co-occurrence, it was found that the supply chain falls under the category of "research objectives and development-strategy research direction". For example, researchers looked at production systems [154], supply network structure and governance mechanisms [155], and supply chain management technology [156] to study the influence of smart cities on the supply chain. Researchers also examined the impact of smart cities on the food supply chain [157]. Despite all of this, research on smart cities and supply chains is currently in the exploratory stage. We note that such trends may not necessarily translate into actual implementation as noted in some of the references, as indeed has been the case in scientific research. Of course, these issues also may be of growing importance in the future. Smart cities incorporate a huge variety of disciplines and our understanding is rapidly evolving. Nevertheless, the degree of integration with other disciplines and research in the context of social ecology needs to be strengthened.

This study is not only intended to help researchers and policy-makers, but also city administrators, planners and funding bodies seeking to capture a broad overview of the directions of research associated with smart-cities. Overall, this research area is continually expanding its scope in order to address urban issues more comprehensively. The complexity of the field will only increase along with the amount of research. This paper tries to clarify this complexity and make sense of the field. Identifying how the smart-city has developed and where challenges and opportunities exist is critical to progress in related to it, and the development of appropriate policy.

Author Contributions: Conceptualization, L.Z. and X.Z.; methodology, L.Z. and X.Z.; software, L.Z.; formal analysis, L.Z.; investigation, L.Z.; resources, L.Z.; data curation, L.Z.; visualization, L.Z.; writing一original draft preparation, L.Z.; writing-review and editing, Z.-y.T. and X.Z.; supervision, Z.T. and X.Z.

Funding: This research received no external funding.

Conflicts of Interest: The authors declare no conflict of interest. 


\section{References}

1. Washburn, D.; Sindhu, U.; Balaouras, S.; Dines, R.A.; Hayes, N.M.; Nelson, L.E. Helping CIOs Understand "Smart City" Initiatives: Defining the Smart City, Its Drivers, and the Role of the CIO; Forrester Research Inc.: Cambridge, MA, USA, 2010; Available online: https://www.forrester.com/report/Helping+CIOs+ Understand+Smart+City+Initiatives/-/E-RES55590\# (accessed on 12 April 2014).

2. Lombardi, P.; Giordano, S.; Farouh, H.; Yousef, W. Modelling the smart city performance. Innov. Eur. J. Soc. Sci. Res. 2012, 25, 137-149. [CrossRef]

3. Caragliu, A.; Del Bo, C.; Nijkamp, P. Smart cities in Europe. J. Urban Technol. 2011, 18, 65-82. [CrossRef]

4. Zanella, A.; Bui, N.; Castellani, A.; Vangelista, L.; Zorzi, M. Internet of things for smart cities. IEEE Int. Things J. 2014, 1, 22-32. [CrossRef]

5. National Development and Reform Commission. Notice on Organizing New Smart-City Evaluations and Promoting the Healthy and Rapid Development of New Smart Cities. 2016. Available online: http://www.ndrc.gov.cn/fzgggz/gjscys/zcfb/201611/t20161128_903474.html (accessed on 13 October 2019).

6. Management and Budget Office. Federal Cloud Computing Strategy. 2018. Available online: https: //cloud.cio.gov/ (accessed on 13 October 2019).

7. Moustaka, V.; Vakali, A.; Anthopoulos, L.G. A systematic review for smart city data analytics. ACM Comput. Surv. 2018, 51, 1-41. [CrossRef]

8. Giffinger, R.; Fertner, C.; Kramar, H.; Kalasek, R.; Pichler-Milanovic', N.; Meijers, E. Smart Cities: Ranking of European Medium-Sized Cities; Centre of Regional Science (SRF), Vienna University of Technology: Vienna, Austria, 2007; Available online: http://www.smart-cities.eu/download/smart_cities_final_report. pdfAccessed10.03.13 (accessed on 13 October 2019).

9. Angelidou, M. Smart city policies: A spatial approach. Cities 2014, 41, S3-S11. [CrossRef]

10. Anthopoulos, L.G.; Reddick, C.G. Understanding electronic government research and smart city: A framework and empirical evidence. Inf. Polity 2016, 21, 99-117. [CrossRef]

11. Su, L.-X.; Lyu, P.-H.; Yang, Z.; Ding, S.; Zhou, K.-L. Scientometric cognitive and evaluation on smart city related construction and building journals data. Scientometrics 2015, 105, 449-470. [CrossRef]

12. Ingwersen, P.; Serrano-López, A.E. Smart city research 1990-2016. Scientometrics 2018, 117, $1205-1236$. [CrossRef]

13. Albino, V.; Berardi, U.; Dangelico, R.M. Smart cities: Definitions, dimensions, performance, and initiatives. J. Urban Technol. 2015, 22, 3-21. [CrossRef]

14. Mora, L.; Bolici, R.; Deakin, M. The first two decades of smart-city research: A bibliometric analysis. J. Urban Technol. 2017, 24, 3-27. [CrossRef]

15. Komninos, N.; Mora, L. Exploring the big picture of smart city research. Sci. Reg. Ital. J. Reg. Sci. 2018, 17, 15-38. [CrossRef]

16. Li, M. Visualizing the studies on smart cities in the past two decades: A two-dimensional perspective. Scientometrics 2019, 120, 683-705. [CrossRef]

17. Jacso, P. As we may search-Comparison of major features of the Web of Science, Scopus, and Google Scholar citation-based and citation-enhanced databases. Curr. Sci. 2005, 89, 1537-1547.

18. Mongeon, P.; Paul-Hus, A. The journal coverage of Web of Science and Scopus: a comparative analysis. Scientometrics 2016, 106, 213-228. [CrossRef]

19. Pritchard, A. Statistical bibliography or bibliometrics. J. Doc. 1969, 25, 348-349.

20. Borgman, C.L.; Furner, J. Scholarly communication and bibliometrics. Annu. Rev. Inf. Sci. Technol. 2002, 36, 2-72. [CrossRef]

21. Thelwall, M. Bibliometrics to webometrics. J. Inf. Sci. 2008, 34, 605-621. [CrossRef]

22. Speel, P.; Shadbolt, N.; Vries, W.D.; Dam, P.V.; O’Hara, K. Knowledge Mapping for Industrial Purposes. 1999. Available online: http://jb4-2.eprints-hosting.org/id/eprint/4841 (accessed on 13 October 2019).

23. Cobo, M.J.; López-Herrera, A.G.; Herrera-Viedma, E.; Herrera, F. Science mapping software tools: Review, analysis, and cooperative study among tools. J. Am. Soc. Inf. Sci. Technol. 2011, 62, 1382-1402. [CrossRef]

24. Persson, O.; Danell, R.; Schneider, J.W. How to use Bibexcel for various types of bibliometric analysis. In Celebrating Scholarly Communication Studies: A Festschrift for Olle Persson at his 60th Birthday; International Society for Scientometrics and Informetrics: Leuven, Belgium, 2009; Volume 5, pp. 9-24. 
25. Bailón-Moreno, R.; Jurado-Alameda, E.; Ruiz-Baños, R. The scientific network of surfactants: Structural analysis. J. Am. Soc. Inf. Sci. Technol. 2006, 57, 949-960. [CrossRef]

26. Eck, N.V.; Waltman, L. Software survey: VOSviewer, a computer program for bibliometric mapping. Scientometrics 2010, 84, 523-538.

27. Chen, C. CiteSpace II: Detecting and visualizing emerging trends and transient patterns in scientific literature. J. Am. Soc. Inf. Sci. Technol. 2006, 57, 359-377. [CrossRef]

28. Pan, X.; Yan, E.; Cui, M.; Hua, W. Examining the usage, citation, and diffusion patterns of bibliometric mapping software: A comparative study of three tools. J. Informetr. 2018, 12, 481-493. [CrossRef]

29. Ahmad, K.; Zheng, J.M.; Rafi, M. Assessing the digital library research output: bibliometric analysis from 2002 to 2016. Electron. Libr. 2018, 36, 696-704. [CrossRef]

30. Moral-Muñoz, J.A.; Carballo-Costa, L.; Herrera-Viedma, E.; Cobo, M.J. Production trends, collaboration, and main topics of the integrative and complementary oncology research area: A bibliometric analysis. Integr. Cancer Ther. 2019, 18. [CrossRef]

31. Yang, D.-W.; Wang, X.-P.; Wang, Z.-C.; Yang, Z.-H.; Bian, X.-F. A scientometric analysis on hepatocellular carcinoma magnetic resonance imaging research from 2008 to 2017. Quant. Imaging Med. Surg. 2019, 9, 465-476. [CrossRef]

32. Iqbal, W.; Qadir, J.; Tyson, G.; Mian, A.N.; Hassan, S.-U.; Crowcroft, J. A bibliometric analysis of publications in computer networking research. Scientometrics 2019, 119, 1121-1155. [CrossRef]

33. Hou, D.; Bi, X.; Mao, Z.; Fan, Y.; Hu, X.; Li, X. Biomaterials research of China from 2013 to 2017 based on bibliometrics and visualization analysis. Peer] 2019, 7, e6859. [CrossRef]

34. Stopar, K.; Bartol, T. Digital competences, computer skills and information literacy in secondary education: mapping and visualization of trends and concepts. Scientometrics 2019, 118, 479-498. [CrossRef]

35. Mahizhnan, A. Smart cities: The Singapore case. Cities 1999, 16, 13-18. [CrossRef]

36. Vázquez-Canteli, J.R.; Ulyanin, S.; Kämpf, J.; Nagy, Z. Fusing TensorFlow with building energy simulation for intelligent energy management in smart cities. Sustain. Cities Soc. 2019, 45, 243-257. [CrossRef]

37. Li, C.; Liu, X.; Dai, Z.; Zhao, Z. Smart city: A shareable framework and its applications in China. Sustainability 2019, 11, 4346. [CrossRef]

38. Vanolo, A. Smartmentality: The smart city as disciplinary strategy. Urban Stud. 2014, 51, 883-898. [CrossRef]

39. Batty, M.; Axhausen, K.W.; Giannotti, F.; Pozdnoukhov, A.; Bazzani, A.; Wachowicz, M.; Portugali, Y. Smart cities of the future. Eur. Phys. J. Spec. Top. 2012, 214, 481-518. [CrossRef]

40. National Development and Reform Commission. Guidance on Promoting the Healthy Development of Smart Cities. 2014. Available online: http://www.ndrc.gov.cn/fzgggz/gjscys/gjsgz/201408/t20140829_905960.html (accessed on 13 October 2019).

41. National Development and Reform Commission. Notice of the Third Batch of National New Urbanization Comprehensive Pilot Areas. 2016. Available online: http://www.ndrc.gov.cn/zcfb/zcfbtz/201612/t20161207_ 829408.html (accessed on 13 October 2019).

42. Dillow, C. How Dubuque is becoming the smartest city in America. Popular Science. 2011. Available online: https://www.popsci.com/science/article/2011-11/data-transforming-dubuque-and-it-will-transformyour-city-too/ (accessed on 21 November 2019).

43. Mattern, S. Instrumental city: The view from Hudson Yards, circa 2019. Places J. 2016. [CrossRef]

44. Schaffers, H.; Komninos, N.; Pallot, M.; Trousse, B.; Nilsson, M.; Oliveira, A. Smart cities and the future internet: Towards cooperation frameworks for open innovation. In The Future Internet Assembly; Springer: Berlin/Heidelberg, Germany, 2011; pp. 431-446. [CrossRef]

45. Cheng, B.; Longo, S.; Cirillo, F.; Bauer, M.; Kovacs, E. Building a big data platform for smart cities: Experience and lessons from Santander. Presented at the 2015 IEEE International Congress on Big Data, New York, NY, USA, 27 June-2 July 2015. [CrossRef]

46. Pollio, A. Technologies of austerity urbanism: the "smart city" agenda in Italy (2011-2013). Urban Geogr. 2016, 37, 514-534. [CrossRef]

47. Giuffrè, T.; Siniscalchi, S.M.; Tesoriere, G. A novel architecture of parking management for smart cities. Procedia Soc. Behav. Sci. 2012, 53, 16-28. [CrossRef]

48. Small, H. Co-citation in the scientific literature: A new measure of the relationship between documents. J. Am. Soc. Inf. Sci. 1973, 42, 676-684. [CrossRef] 
49. Neirotti, P.; De Marco, A.; Cagliano, A.C.; Mangano, G.; Scorrano, F. Current trends in Smart City initiatives: Some stylised facts. Cities 2014, 38, 25-36. [CrossRef]

50. Hollands, R.G. Will the real smart city please stand up? City 2008, 12, 303-320. [CrossRef]

51. Atzori, L.; Iera, A.; Morabito, G. The internet of things: A survey. Comput. Netw. 2010, 54, 2787-2805. [CrossRef]

52. Gubbi, J.; Buyya, R.; Marusic, S.; Palaniswami, M. Internet of things (IoT): A vision, architectural elements, and future directions. Future Gener. Comput. Syst. 2013, 29, 1645-1660. [CrossRef]

53. Kitchin, R. The real-time city? Big data and smart urbanism. GeoJournal 2014, 79, 1-14. [CrossRef]

54. Hollands, R.G. Critical interventions into the corporate smart city. Camb. J. Reg. Econ. Soc. 2014, 8, 61-77. [CrossRef]

55. Kitchin, R. Big data and human geography: Opportunities, challenges and risks. Dialogues Hum. Geogr. 2013, 3, 262-267. [CrossRef]

56. Söderström, O.; Paasche, T.; Klauser, F. Smart cities as corporate storytelling. City 2014, 18, 307-320. [CrossRef]

57. Lee, J.H.; Hancock, M.G.; Hu, M.-C. Towards an effective framework for building smart cities: Lessons from Seoul and San Francisco. Technol. Forecast. Soc. Chang. 2014, 89, 80-99. [CrossRef]

58. Bakıc1, T.; Almirall, E.; Wareham, J. A smart city initiative: The case of Barcelona. J. Knowl. Econ. 2013, 4, 135-148. [CrossRef]

59. Nam, T.; Pardo, T.A. Conceptualizing smart city with dimensions of technology, people, and institutions. Presented at the 12th Annual International Digital Government Research Conference: Digital Government Innovation in Challenging Times, College Park, MD, USA, 12-15 June 2011. [CrossRef]

60. Chourabi, H.; Nam, T.; Walker, S.; Gil-Garcia, J.R.; Mellouli, S.; Nahon, K.; Scholl, H.J. Understanding smart cities: An integrative framework. Presented at the 2012 45th Hawaii International Conference on System Sciences, Washington, DC, USA, 4-7 January 2012. [CrossRef]

61. Yang, B. Developing a mobile mapping system for 3D GIS and smart city planning. Sustainability 2019, 11, 3713. [CrossRef]

62. Castelnovo, W.; Misuraca, G.; Savoldelli, A. Smart cities governance: The need for a holistic approach to assessing urban participatory policy making. Soc. Sci. Comput. Rev. 2016, 34, 724-739. [CrossRef]

63. Boes, K.; Buhalis, D.; Inversini, A. Smart tourism destinations: Ecosystems for tourism destination competitiveness. Int. J. Tour. Cities 2016, 2, 108-124. [CrossRef]

64. Yu, Z.; Haghighat, F.; Fung, B.C.M. Advances and challenges in building engineering and data mining applications for energy-efficient communities. Sustain. Cities Soc. 2016, 25, 33-38. [CrossRef]

65. Ahvenniemi, H.; Huovila, A.; Pinto-Seppä, I.; Airaksinen, M. What are the differences between sustainable and smart cities? Cities 2017, 60, 234-245. [CrossRef]

66. Silva, B.N.; Khan, M.; Han, K. Towards sustainable smart cities: A review of trends, architectures, components, and open challenges in smart cities. Sustain. Cities Soc. 2018, 38, 697-713. [CrossRef]

67. Bibri, S.E.; Krogstie, J. Smart sustainable cities of the future: An extensive interdisciplinary literature review. Sustain. Cities Soc. 2017, 31, 183-212. [CrossRef]

68. Bibri, S.E. The IoT for smart sustainable cities of the future: An analytical framework for sensor-based big data applications for environmental sustainability. Sustain. Cities Soc. 2018, 38, 230-253. [CrossRef]

69. Cocchia, A. Smart and digital city: A systematic literature review. In Smart City: How to Create Public and Economic Value with High Technology in Urban Space; Dameri, R.P., Rosenthal-Sabroux, C., Eds.; Springer International Publishing: Cham, Switzerland, 2014; pp. 13-43. [CrossRef]

70. Roman, R.; Zhou, J.; Lopez, J. On the features and challenges of security and privacy in distributed internet of things. Comput. Netw. 2013, 57, 2266-2279. [CrossRef]

71. Whitmore, A.; Agarwal, A.; Da Xu, L. The internet of things-A survey of topics and trends. Inf. Syst. Front. 2015, 17, 261-274. [CrossRef]

72. Sethi, P.; Sarangi, S.R. Internet of things: Architectures, protocols, and applications. J. Electr. Comput. Eng. 2017, 2017. [CrossRef]

73. Qiu, T.; Chen, N.; Li, K.; Atiquzzaman, M.; Zhao, W. How can heterogeneous internet of things build our future: A survey. IEEE Commun. Surv. Tutor. 2018, 20, 2011-2027. [CrossRef] 
74. Jeschke, S.; Brecher, C.; Meisen, T.; Özdemir, D.; Eschert, T. Industrial internet of things and cyber manufacturing systems. In Industrial Internet of Things: Cybermanufacturing Systems; Jeschke, S., Brecher, C., Song, H., Rawat, D.B., Eds.; Springer International Publishing: Cham, Switzerland, 2017; pp. 3-19. [CrossRef]

75. Hashem, I.A.T.; Chang, V.; Anuar, N.B.; Adewole, K.; Yaqoob, I.; Gani, A.; Chiroma, H. The role of big data in smart city. Int. J. Inf. Manag. 2016, 36, 748-758. [CrossRef]

76. Balakrishna, C. Enabling technologies for smart city services and applications. Presented at the 2012 Sixth International Conference on Next Generation Mobile Applications, Services and Technologies, Paris, France, 12-14 September 2012. [CrossRef]

77. Villegas-Ch, W.; Palacios-Pacheco, X.; Luján-Mora, S. Application of a smart city model to a traditional university campus with a big data architecture: A sustainable smart campus. Sustainability 2019, 11, 2857. [CrossRef]

78. Jegadeesan, S.; Azees, M.; Kumar, P.M.; Manogaran, G.; Chilamkurti, N.; Varatharajan, R.; Hsu, C.-H. An efficient anonymous mutual authentication technique for providing secure communication in mobile cloud computing for smart city applications. Sustain. Cities Soc. 2019, 49, 101522. [CrossRef]

79. Petrolo, R.; Loscr, V.; Mitton, N. Towards a smart city based on cloud of things. Presented at the 2014 ACM International Workshop on Wireless and Mobile Technologies for Smart Cities 2014, Philadelphia, PA, USA, 11 August 2014. [CrossRef]

80. Petrolo, R.; Loscrì, V.; Mitton, N. Towards a smart city based on cloud of things, a survey on the smart city vision and paradigms. Trans. Emerg. Telecommun. Technol. 2017, 28, e2931. [CrossRef]

81. Chen, M. Towards smart city: M2M communications with software agent intelligence. Multimed. Tools Appl. 2013, 67, 167-178. [CrossRef]

82. Al-Fuqaha, A.; Guizani, M.; Mohammadi, M.; Aledhari, M.; Ayyash, M. Internet of things: A survey on enabling technologies, protocols, and applications. IEEE Commun. Surv. Tutor. 2015, 17, 2347-2376. [CrossRef]

83. Giang, N.K.; Blackstock, M.; Lea, R.; Leung, V.C.M. Developing IoT applications in the fog: A Distributed dataflow approach. Presented at the 2015 5th International Conference on the Internet of Things (IOT), Seoul, Korea, 26-28 October 2015. [CrossRef]

84. Stritih, U.; Tyagi, V.V.; Stropnik, R.; Paksoy, H.; Haghighat, F.; Joybari, M.M. Integration of passive PCM technologies for net-zero energy buildings. Sustain. Cities Soc. 2018, 41, 286-295. [CrossRef]

85. Mijumbi, R.; Serrat, J.; Gorricho, J.; Bouten, N.; Turck, F.D.; Boutaba, R. Network function virtualization: State-of-the-art and research challenges. IEEE Commun. Surv. Tutor. 2016, 18, 236-262. [CrossRef]

86. Botta, A.; de Donato, W.; Persico, V.; Pescapé, A. Integration of cloud computing and internet of things: A survey. Future Gener. Comput. Syst. 2016, 56, 684-700. [CrossRef]

87. Shi, W.; Cao, J.; Zhang, Q.; Li, Y.; Xu, L. Edge computing: Vision and challenges. IEEE Int. Things J. 2016, 3, 637-646. [CrossRef]

88. Walravens, N. Mobile city applications for Brussels citizens: Smart city trends, challenges and a reality check. Telemat. Inform. 2015, 32, 282-299. [CrossRef]

89. Shelton, T.; Zook, M.; Wiig, A. The 'actually existing smart city'. Camb. J. Reg. Econ. Soc. 2014, 8, 13-25. [CrossRef]

90. Kitchin, R. Big data, new epistemologies and paradigm shifts. Big Data Soc. 2014, 1. [CrossRef]

91. Abbasi, A.; Sarker, S.; Chiang, R.H.L. Big data research in information systems: Toward an inclusive research agenda. J. Assoc. Inf. Syst. 2016, 17, I-XXXII. [CrossRef]

92. Akter, S.; Wamba, S.F.; Gunasekaran, A.; Dubey, R.; Childe, S.J. How to improve firm performance using big data analytics capability and business strategy alignment? Int. J. Prod. Econ. 2016, 182, 113-131. [CrossRef]

93. Al Nuaimi, E.; Al Neyadi, H.; Mohamed, N.; Al-Jaroodi, J. Applications of big data to smart cities. J. Int. Serv. Appl. 2015, 6, 25. [CrossRef]

94. Sheng, J.; Amankwah-Amoah, J.; Wang, X. A multidisciplinary perspective of big data in management research. Int. J. Prod. Econ. 2017, 191, 97-112. [CrossRef]

95. Kitchin, R. Making sense of smart cities: Addressing present shortcomings. Camb. J. Reg. Econ. Soc. 2014, 8, 131-136. [CrossRef]

96. Buhalis, D.; Amaranggana, A. Smart tourism destinations enhancing tourism experience through personalisation of services. Presented at the Information and Communication Technologies in Tourism 2015, Cham, Switzerland, 3-6 February 2015. [CrossRef] 
97. March, H.; Ribera-Fumaz, R. Smart contradictions: The politics of making Barcelona a self-sufficient city. Eur. Urban Reg. Stud. 2016, 23, 816-830. [CrossRef]

98. Buhalis, D.; Amaranggana, A. Smart Tourism Destinations. Presented at the Information and Communication Technologies in Tourism 2014, Cham, Switzerland, 21-24 January 2014. [CrossRef]

99. Ben Letaifa, S. How to strategize smart cities: Revealing the SMART model. J. Bus. Res. 2015, 68, 1414-1419. [CrossRef]

100. Luque-Ayala, A.; Marvin, S. Developing a critical understanding of smart urbanism? Urban Stud. 2015, 52, 2105-2116. [CrossRef]

101. De Lange, M.; de Waal, M. Owning the city: New media and citizen engagement in urban design. In Urban Land Use; Apple Academic Press: Palm Bay, FL, USA, 2013. [CrossRef]

102. Kummitha, R.K.R.; Crutzen, N. How do we understand smart cities? An evolutionary perspective. Cities 2017, 67, 43-52. [CrossRef]

103. Anthopoulos, L. Smart utopia VS smart reality: Learning by experience from 10 smart city cases. Cities 2017, 63, 128-148. [CrossRef]

104. Goodspeed, R. Smart cities: Moving beyond urban cybernetics to tackle wicked problems. Camb. J. Reg. Econ. Soc. 2014, 8, 79-92. [CrossRef]

105. Vanolo, A. Is there anybody out there? The place and role of citizens in tomorrow's smart cities. Futures 2016, 82, 26-36. [CrossRef]

106. Kleinberg, J. Bursty and hierarchical structure in streams. Data Min. Knowl. Discov. 2003, 7, $373-397$. [CrossRef]

107. Shapiro, J.M. Smart cities: Quality of life, productivity, and the growth effects of human capital. Rev. Econ. Stat. 2006, 88, 324-335. [CrossRef]

108. Naphade, M.; Banavar, G.; Harrison, C.; Paraszczak, J.; Morris, R. Smarter cities and their innovation challenges. Computer 2011, 44, 32-39. [CrossRef]

109. Komninos, N. Intelligent Cities and Globalisation of Innovation Networks; Routledge: London, UK, 2008. [CrossRef]

110. Cardone, G.; Cirri, A.; Corradi, A.; Foschini, L. The participact mobile crowd sensing living lab: The testbed for smart cities. IEEE Commun. Mag. 2014, 52, 78-85. [CrossRef]

111. Tranos, E.; Gertner, D. Smart networked cities? Innov. Eur. J. Soc. Sci. Res. 2012, 25, 175-190. [CrossRef]

112. Mitton, N.; Papavassiliou, S.; Puliafito, A.; Trivedi, K.S. Combining cloud and sensors in a smart city environment. EURASIP J. Wirel. Commun. Netw. 2012, 2012, 247. [CrossRef]

113. González, M.C.; Hidalgo, C.A.; Barabási, A.-L. Understanding individual human mobility patterns. Nature 2008, 453, 779-782. [CrossRef]

114. Alawadhi, S.; Aldama-Nalda, A.; Chourabi, H.; Gil-Garcia, J.R.; Leung, S.; Mellouli, S.; Walker, S. Building understanding of smart city initiatives. In International Conference on Electronic Government; Springer: Berlin/Heidelberg, Germany, 2012. [CrossRef]

115. Nam, T.; Pardo, T.A. Smart city as urban innovation: focusing on management, policy, and context. Presented at the 5th International Conference on Theory and Practice of Electronic Governance, Tallinn, Estonia, 26-28 September 2011. [CrossRef]

116. Meijer, A.; Bolívar, M.P.R. Governing the smart city: A review of the literature on smart urban governance. Int. Rev. Adm. Sci. 2015, 82, 392-408. [CrossRef]

117. Leonidas, A.; Marijn, J.; Vishanth, W.A.; Marijn, J.; Vishanth, W. A Unified Smart City Model (USCM) for smart city conceptualization and benchmarking. In Smart Cities and Smart Spaces: Concepts, Methodologies, Tools, and Applications; Information Resources Management Association, Ed.; IGI Global: Hershey, PA, USA, 2019. [CrossRef]

118. Benevolo, C.; Dameri, R.P.; D’Auria, B. Smart mobility in smart city. In Empowering Organizations; Springer: Cham, Switzerland, 2016. [CrossRef]

119. Lee, J.; Lee, H. Developing and validating a citizen-centric typology for smart city services. Gov. Inf. Q. 2014, 31, S93-S105. [CrossRef]

120. Monzon, A. Smart cities concept and challenges: Bases for the assessment of smart city projects. Presented at the 2015 International Conference on Smart Cities and Green ICT Systems (SMARTGREENS), Lisbon, Portugal, 20-22 May 2015. 
121. Winters, J.V. Why are smart cities growing? Who moves and who stays. J. Reg. Sci. 2011, 51, $253-270$. [CrossRef]

122. Zhang, K.; Ni, J.; Yang, K.; Liang, X.; Ren, J.; Shen, X.S. Security and privacy in smart city applications: Challenges and solutions. IEEE Commun. Mag. 2017, 55, 122-129. [CrossRef]

123. Scuotto, V.; Ferraris, A.; Bresciani, S. Internet of things: Applications and challenges in smart cities: A case study of IBM smart city projects. Bus. Process Manag. J. 2016, 22, 357-367. [CrossRef]

124. Jalali, R.; El-khatib, K.; McGregor, C. Smart city architecture for community level services through the internet of things. Presented at the 2015 18th International Conference on Intelligence in Next Generation Networks, Paris, France, 17-19 February 2015. [CrossRef]

125. Clohessy, T.; Acton, T.; Morgan, L. Smart City as a Service (SCaaS): A future roadmap for E-government smart city cloud computing initiatives. Presented at the 2014 IEEE/ACM 7th International Conference on Utility and Cloud Computing, Washington, DC, USA, 8-11 December 2014. [CrossRef]

126. Zygiaris, S. Smart city reference model: Assisting planners to conceptualize the building of smart city innovation ecosystems. J. Knowl. Econ. 2013, 4, 217-231. [CrossRef]

127. Deakin, M.; Al Waer, H. From intelligent to smart cities. Intell. Build. Int. 2011, 3, 140-152. [CrossRef]

128. Vinod Kumar, T.M.; Dahiya, B. Smart economy in smart cities. In Smart Economy in Smart Cities; International Collaborative Research: Ottawa, St. Louis, Stuttgart, Bologna, Cape Town, Nairobi, Dakar, Lagos, New Delhi, Varanasi, Vijayawada, Kozhikode, Hong Kong; Vinod Kumar, T.M., Ed.; Springer: Singapore, 2017; pp. 3-76.

129. Torres-Sospedra, J.; Avariento, J.; Rambla, D.; Montoliu, R.; Casteleyn, S.; Benedito-Bordonau, M.; Huerta, J. Enhancing integrated indoor/outdoor mobility in a smart campus. Int. J. Geogr. Inf. Sci. 2015, 29, 1955-1968. [CrossRef]

130. Eslamian, S.A.; Li, S.S.; Haghighat, F. A new multiple regression model for predictions of urban water use. Sustain. Cities Soc. 2016, 27, 419-429. [CrossRef]

131. Di Nardo, A.; Di Natale, M.; Santonastaso, G.F.; Venticinque, S. An automated tool for smart water network partitioning. Water Resour. Manag. 2013, 27, 4493-4508. [CrossRef]

132. Xiao, M.; Wu, J.; Huang, L.; Wang, Y.; Liu, C. Multi-task assignment for crowdsensing in mobile social networks. Presented at the 2015 IEEE Conference on Computer Communications (INFOCOM), Hong Kong, China, 26 April-1 May 2015. [CrossRef]

133. Xiong, H.; Zhang, D.; Chen, G.; Wang, L.; Gauthier, V. CrowdTasker: Maximizing coverage quality in Piggyback Crowdsensing under budget constraint. Presented at the 2015 IEEE International Conference on Pervasive Computing and Communications (PerCom), St. Louis, MO, USA, 23-27 March 2015. [CrossRef]

134. Zhang, D.; Wang, L.; Xiong, H.; Guo, B. 4W1H in mobile crowd sensing. IEEE Commun. Mag. 2014, 52, 42-48. [CrossRef]

135. Zhang, D.; Xiong, H.; Wang, L.; Chen, G. CrowdRecruiter: Selecting participants for piggyback crowdsensing under probabilistic coverage constraint. Presented at the 2014 ACM International Joint Conference on Pervasive and Ubiquitous Computing, Washington, DC, USA, 13-17 September 2014. [CrossRef]

136. Hu, X.; Li, X.; Ngai, E.C.; Leung, V.C.M.; Kruchten, P. Multidimensional context-aware social network architecture for mobile crowdsensing. IEEE Commun. Mag. 2014, 52, 78-87. [CrossRef]

137. Lee, K.A.; Larcher, A.; Wang, G.; Kenny, P.; Brümmer, N.; Leeuwen, D.V.; Ma, B. The RedDots data collection for speaker recognition. Presented at the Sixteenth Annual Conference of the International Speech Communication Association, Dresden, Germany, 6-10 September 2015.

138. Piro, G.; Cianci, I.; Grieco, L.A.; Boggia, G.; Camarda, P. Information centric services in smart cities. J. Syst. Softw. 2014, 88, 169-188. [CrossRef]

139. Mattoni, B.; Gugliermetti, F.; Bisegna, F. A multilevel method to assess and design the renovation and integration of smart cities. Sustain. Cities Soc. 2015, 15, 105-119. [CrossRef]

140. Massana, J.; Pous, C.; Burgas, L.; Melendez, J.; Colomer, J. Identifying services for short-term load forecasting using data driven models in a smart city platform. Sustain. Cities Soc. 2017, 28, 108-117. [CrossRef]

141. Rathore, M.M.; Ahmad, A.; Paul, A.; Rho, S. Urban planning and building smart cities based on the internet of things using big data analytics. Comput. Netw. 2016, 101, 63-80. [CrossRef]

142. Iqbal, J.; Khan, M.; Talha, M.; Farman, H.; Jan, B.; Muhammad, A.; Khattak, H.A. A generic internet of things architecture for controlling electrical energy consumption in smart homes. Sustain. Cities Soc. 2018, 43, 443-450. [CrossRef] 
143. Park, S.; Lee, S.; Park, S.; Park, S. AI-based physical and virtual platform with 5-layered architecture for sustainable smart energy city development. Sustainability 2019, 11, 4479. [CrossRef]

144. Kauf, S. Smart logistics as a basis for the development of the smart city. Transp. Res. Procedia 2019, 39, 143-149. [CrossRef]

145. Korczak, J.; Kijewska, K. Smart logistics in the development of smart cities. Transp. Res. Procedia 2019, 39, 201-211. [CrossRef]

146. Gohar, M.; Muzammal, M.; Ur Rahman, A. SMART TSS: Defining transportation system behavior using big data analytics in smart cities. Sustain. Cities Soc. 2018, 41, 114-119. [CrossRef]

147. Jiang, L.; Ye, S.; Zhao, L.; Ma, X.; Yang, X. Medical image super-resolution for remote medical diagnosis in smart city: A case study based on the new healthcare reform of China. Sustain. Cities Soc. 2019, 48, 101497. [CrossRef]

148. Gouveia, C.; Fonseca, A. New approaches to environmental monitoring: the use of ICT to explore volunteered geographic information. GeoJournal 2008, 72, 185-197. [CrossRef]

149. Jin, J.; Gubbi, J.; Marusic, S.; Palaniswami, M. An information framework for creating a smart city through internet of things. IEEE Int. Things J. 2014, 1, 112-121. [CrossRef]

150. Toppeta, D. The smart city vision: How innovation and ICT can build smart, "livable", sustainable cities. Innov. Knowl. Found. 2010, 5, 1-9.

151. Eremia, M.; Toma, L.; Sanduleac, M. The smart city concept in the 21st century. Procedia Eng. 2017, 181, 12-19. [CrossRef]

152. David, M.; Koch, F. “Smart is not smart enough!” Anticipating critical raw material use in smart city concepts: The example of smart grids. Sustainability 2019, 11, 4422. [CrossRef]

153. Gong, S.; Tcydenova, E.; Jo, J.; Lee, Y.; Park, J.H. Blockchain-based secure device management framework for an internet of things network in a smart city. Sustainability 2019, 11, 3889. [CrossRef]

154. Kumar, M.; Graham, G.; Hennelly, P.; Srai, J. How will smart city production systems transform supply chain design: A product-level investigation. Int. J. Prod. Res. 2016, 54, 7181-7192. [CrossRef]

155. Tachizawa, E.M.; Alvarez-Gil, M.J.; Montes-Sancho, M.J. How "smart cities" will change supply chain management. Supply Chain Manag. Int. J. 2015, 20, 237-248. [CrossRef]

156. Öberg, C.; Graham, G. How smart cities will change supply chain management: A technical viewpoint. Prod. Plan. Control 2016, 27, 529-538. [CrossRef]

157. Zhang, Q.; Huang, T.; Zhu, Y.; Qiu, M. A case study of sensor data collection and analysis in smart city: Provenance in smart food supply chain. Int. J. Distrib. Sens. Netw. 2013, 9, 382132. [CrossRef] 